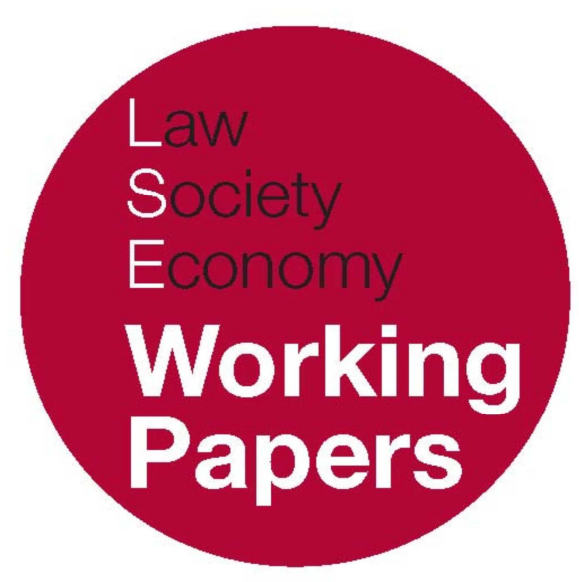

\title{
The Costs of Separation: \\ Friction between Company and Insolvency \\ Law in the Single Market
}

Carsten Gerner-Beuerle and Edmund Schuster

LSE Law, Society and Economy Working Papers 6/2014

London School of Economics and Political Science

Law Department

This paper can be downloaded without charge from LSE Law, Society and Economy Working Papers at: www.lse.ac.uk/collections/law/wps/wps.htm and the Social Sciences Research Network electronic library at: http://ssrn.com/abstract $=2346676$.

(C) Carsten Gerner-Beuerle and Edmund Schuster. Users may download and/or print one copy to facilitate their private study or for non-commercial research. Users may not engage in further distribution of this material or use it for any profit-making activities or any other form of commercial gain. 


\title{
The Costs of Separation: \\ Friction between Company and Insolvency Law in the Single Market
}

\author{
Carsten Gerner-Beuerle ${ }^{*}$ and Edmund Schuster ${ }^{* *}$
}

\begin{abstract}
Corporate mobility and choice of law within the EU has dominated much of the academic writing in European company law over the last decades. What has not yet received much attention is the way in which national company law interacts with and depends on features of the national legal system outside of company law. In this article we explore this interaction and its relevance for coherent national regulatory systems.

Using the regulatory framework for companies in the 'vicinity of insolvency' as an example, we show how choice of company law can create both regulatory gaps and multiplication of legal requirements, as private international law rules are applied inconsistently across Europe. More importantly, however, we show that even consistent application of conflicts rules would fail to resolve these problems due to cross-doctrinal interdependence within any national legal system.

We conclude that this is a design flaw in the way EU law deals with the increasingly international reach of corporations, and discuss possible paths for resolving or mitigating this issue.
\end{abstract}

\footnotetext{
* Associate Professor, Law Department, London School of Economics and Political Science.

** Assistant Professor, Law Department, London School of Economics and Political Science. We are very grateful to John Armour, Jacco Bomhoff, Damian Chalmers, Brian Cheffins, Paul Davies, Eilis Ferran, David Kershaw, Jonathan Rickford, Wolf-Georg Ringe, Michael Schillig, and Richard Williams for valuable comments on an earlier draft. The usual disclaimers apply.
} 


\section{A. INTRODUCTION}

The increase in corporate mobility in Europe and its impact on different aspects of company law has dominated much of the academic writing in European company law over the last two decades. ${ }^{1}$ More recently, forum shopping and regulatory arbitrage in corporate insolvency have gained the attention of legal commentators, as an increasing number of companies have made use of foreign law rescue procedures they considered superior to what was on offer in their home legal systems. ${ }^{2}$ However, debates about the effects of forum shopping have not fully appreciated the extent to which all national company law systems depend on aspects of adjacent areas of national law in order to achieve the desired regulatory outcomes.

Company law, insolvency law, and to some extent other areas of law such as tort, administrative, and criminal law, interact with each other in complex ways to form integrated, coherent regulatory systems on the national level. These legal areas are functionally interdependent; they have developed in parallel over time as jurisdictions have made different choices of how to distribute regulatory tasks between them to address similar problems.

The growing importance of corporate mobility has the potential to tear these coherent systems apart. Private international law rules, relying on a range of different connecting factors across different legal areas, are tasked with rebuilding this regulatory framework across borders, using legal 'building blocks' of different origin, as companies establish connections with various jurisdictions. In doing so, they may, however, fail in three distinct ways. First, inconsistencies in the application of private international law rules may fail to create a complete regulatory

\footnotetext{
1 J Armour, 'Who Should Make Corporate Law? EC Legislation versus Regulatory Competition' (2005) 58 Current Legal Problems 369; L Enriques and M Gelter, 'Regulatory Competition in European Company Law and Creditor Protection' (2006) 7 European Business Organization Law Review 417; M Gelter, 'The Structure of Regulatory Competition in European Corporate Law' (2005) 5 Journal of Corporate Law Studies 247; L Hornuf, Regulatory Competition in European Corporate and Capital Markets Law (Cambridge, Intersentia, 2012); C Timmermans, 'Impact of EU Law on International Company Law' (2010) 18 European Review of Private Law 549; C Kirchner, RW Painter, and WA Kaal, 'Regulatory Competition in EU Corporate Law after Inspire Art: Unbundling Delaware's Product for Europe' (2005) 2 European Company and Financial Law 159.

2 JA McCahery, 'Creditor Protection in a Cross-Border Context' (2006) 7 European Business Organization Law Review 455; G McCormack, Jurisdictional Competition and Forum Shopping in Insolvency Proceedings' (2009) 68 Cambridge Law Journal 169; H Eidenmüller, 'Free Choice in International Company Insolvency Law in Europe' (2005) 6 European Business Organization Law Review 423; M Menjucq, 'Towards the End of the Real Seat Theory in Europe?' in: M Tison and others (eds), Perspectives in Company Law and Financial Regulation - Essays in Honour of Eddy Wymeersch (Cambridge University Press, 2009), 124; WG Ringe, 'Forum Shopping under the EU Insolvency Regulation' (2008) 9 European Business Organization Lan Review 579; WG Ringe, 'Strategic Insolvency Migration and Community Law', in WG Ringe, L Gullifer, and P Théry (eds), Current Issues in European Financial and Insolvency Law (Oxford and Portland, Oregon, Hart, 2009), 71. The issue has also received much attention in the US under the rubric of forum shopping. Bankruptcy law is federal law, but it may be interpreted and applied differently by the courts, with potentially important implications for the outcome of the case, see LM LoPucki and WC Whitford, 'Venue Choice and Forum Shopping in the Bankruptcy Reorganization of Large, Publicly Held Companies' (1991) Wisconsin Law Review 11.
} 
framework. Certain rules or types of rules are disapplied in their entirety, resulting in regulatory gaps as some of the building blocks are not made available despite their existence in each of the national legal systems involved. Second, such inconsistencies may lead to the application of multiple and sometimes conflicting rules of the same type, thus rendering movement across frontiers more costly for companies. Third, and perhaps most importantly, completeness and lack of overlap are necessary, but not sufficient conditions for the coherence of a regulatory system. This last point goes beyond the problems created by conflicting or illcoordinated private international law rules. The efficacy of regulatory strategies depends on various legal and non-legal determinants, for example of a cultural or institutional nature. The nature and quality of these determinants will have played a pivotal role in how the distribution of regulatory tasks across different legal areas evolved over time, and legal systems will thus place different emphasis on the strategies at their disposal in regulating a common conflict. As the strategies are dissected and re-assembled across borders, the resulting regulatory framework may be complete in the sense that each inapplicable strategy of state A is replaced by a functional substitute of state $\mathrm{B}$, but it may nevertheless fail to regulate the social conflict effectively. We observe this problem in various constellations, pointing to a fundamental design flaw in the way we deal with the increasingly international reach of domestic companies.

This paper examines these problems by analysing an area where functional interdependence is especially pronounced and which, accordingly, seems wellsuited to highlight the practical relevance of the problems. We focus on the regulatory framework in relation to companies in the 'vicinity of insolvency' and show how conflict of law rules and the territorial reach of administrative and criminal mechanisms give rise to substantial frictions in cross-border situations. We explore how these frictions create legal uncertainty and result in incoherent regulatory solutions, and we investigate the impact this may have on the efficient functioning of debt markets.

The paper proceeds as follows. Section B will provide an overview of the legal framework for corporate mobility in Europe and the theoretical justification for mutual recognition of foreign-incorporated companies. In Section C, we will examine a number of legal strategies used in Europe to address the economic problems that arise in relation to companies in the vicinity of insolvency and analyse their international scope of application. Section D will focus on how corporate mobility and conflict of law rules may result in the application of incoherent, incomplete, and often inefficient rules to companies making use of their Treaty freedoms. Section E contains a number of possible solutions to the problems identified in Section $\mathrm{D}$ as well as our tentative conclusions. 


\section{B. CORPORATE MOBILITY, MUTUAL RECOGNITION, AND REGULATORY ARBITRAGE}

\section{CORPORATE Mobility IN EUROPE}

As we will explain in more detail below, the problems addressed in this paper are for the most part direct consequences of the exercise by companies of the freedom of establishment enshrined in the Treaty, and the resulting concurrent application of different national rules across a number of legal areas. Before analysing these problems, it thus seems useful to briefly review the regulatory framework governing corporate mobility in the EU.

Corporate mobility has rightly been described as the 'very essence of the internal market ${ }^{3}$ as far as company law is concerned, and it clearly lies at the heart of European company law. The way corporate mobility has developed in Europe goes hand-in-hand with choice of law: by granting corporations the right to engage in cross-border business operations - be it through branches or otherwise - the Member States have undoubtedly accepted an obligation to tolerate the application and operation of foreign legal concepts within their national economies.

The drafters of the Treaty were of course aware of the possible problems this 'intrusion' of foreign companies into the territory of the different Member States could create. To resolve these issues - particularly the question of when a company formed under the law of one Member State would have to be recognised ${ }^{4}$ - the Treaty envisaged a multilateral convention among the Member States. ${ }^{5}$ Although the Member States agreed on the text of such a convention in $1968,{ }^{6}$ it was never ratified. In 2007, the drafters of the Lisbon Treaty apparently felt that such a convention was no longer necessary, and Article 293 TEC has now been repealed. ${ }^{7}$

The perceived redundancy of the multilateral convention envisaged by Article 293 TEC can easily be traced back to developments in the ECJ's jurisprudence over the last decade or so. In a number of landmark decisions the Court clarified

\footnotetext{
${ }^{3} \mathrm{KJ}$ Hopt, 'The European Company Law Action Plan: An Introduction' in: KJ Hopt and K Geens (eds), The European Company Law Action Plan Revisited (Leuven, Leuven University Press 2010), 18.

${ }^{4}$ We use the term recognition to refer to a situation where the host Member State's legal system (i) treats the company in question as a legal entity, thereby accepting the legal status granted under the law of its formation, and (ii) where it accepts that the core arrangements of internal governance are also to be determined under that law.

${ }^{5}$ See Article 293 TEC (ex Article 220 EEC) stated that Member States shall, in so far as necessary, engage in negotiations with each other with a view to ensuring for the benefit of their nationals [...] the mutual recognition of companies within the meaning of [what is now Art 54(2) TFEU], the maintenance of their legal personality in cases where the registered office is transferred from one country to another, and the possibility for companies subject to the municipal law of different Member States to form mergers'.

${ }^{6}$ See Convention on the Mutual Recognition of Companies and Bodies Corporate (signed on 29 February 1968), Bulletin of the European Communities Supplement No. 2-1969. See J Rickford, 'Current Developments in European Law on the Restructuring of Companies: An Introduction' (2004) 15 European Business Law Review 1225, 1236.

${ }^{7}$ See Treaty of Lisbon (2007), OJ C 306, 17.12.2007, Article 2 (280).
} 
the most important issues regarding company recognition. It overwhelmingly did so in favour of corporate mobility. While in its Daily Mail decision ${ }^{8}$ the Court still seemed to attach significance to the fact that no convention had been concluded between Member States to address problems of corporate mobility, ${ }^{9}$ this was no longer seen as relevant by the Court in subsequent cases. Beginning with Centros, ${ }^{10}$ the Court has developed what can be described as essentially a mutual recognition approach for EU-incorporated companies, based directly on Articles 49 and 54 TFEU. In Überseering 11 the Court expressly clarified that the exercise of the freedom of establishment does indeed not depend on any additional agreement among Member States, and in particular that the Treaty in envisaging a convention did not create a 'reserved area' for national legislation outside the Court's scrutiny. ${ }^{12}$ Thus, effectively, the Court ruled that the Treaty contains a very broad mandate to 'tolerate' companies formed under foreign law operating within their territory, and in doing so made clear that restrictive national conflicts of law rules will have to be disapplied unless justified.

Importantly, the Court also made clear that this 'tolerance' towards foreignincorporated entities (i.e. the obligation to recognise them as such) does not depend in any way on them carrying out any business activity in their countries of formation. ${ }^{13}$ The Court held that choice of the company law that an incorporator considers to be the most advantageous is inherent in the exercise, in a single market, of the freedom of establishment', and that this holds true even where businesses adopt a particular structure for the sole reason of becoming subject to their preferred law. ${ }^{14}$ It is widely acknowledged that the line of cases started by Centros opened the door to choice of law - and thus regulatory arbitrage - within the EU. ${ }^{15}$ Rather than treating 'pure' choice of law (i.e. situations where choice of law is the sole reason for

\footnotetext{
${ }^{8}$ Case 81/87 The Queen v HM Treasury and Commissioners for Inland Revenue, exp Daily Mail and General Trust plc [1988] ECR 5483.

9 See ibid, para 21-23. Note, however, that the Court in Daily Mail only mentioned the convention in relation to the 'retention of legal personality in the event of transfer of the registered office of companies from one country to another'.

${ }^{10}$ Case C-212/97 Centros Ltd v Erhverus- og Selskabsstyrelsen [1999] ECR I-1459 at para 27.

${ }_{11}$ Case C-208/00 Überseering BV v Nordic Construction Company Baumanagement GmbH (NCC) [2002] I-9919.

${ }_{12} \mathrm{Ibid}$ para 54. See e.g. WF Ebke, 'The European Conflict-of-Corporate-Laws Revolution: Überseering, Inspire Art and Beyond' (2004) 38 International Lanyer 813, 824-825; WG Ringe, 'The European Company Statute in the Context of Freedom of Establishment' (2007) 7 Journal of Corporate Law Studies 185, 194; C Gerner-Beuerle and M Schillig, 'The Mysteries of Freedom of Establishment After Cartesio' (2010) 59 International and Comparative Law Quarterly 303; C Gerner-Beuerle, 'United in Diversity: Maximum versus Minimum Harmonization in EU Securities Regulation' (2012) 7 Capital Markets Law Journal 317, 338.

${ }^{13}$ By country of incorporation we refer to the jurisdiction under whose laws the company acquired its status (i.e. under whose laws it was 'formed').

14 See Case C-167/01 Kamer van Koophandel en Fabrieken voor Amsterdam v Inspire Art Ltd [2003] ECR I-10195 at para 121, and Centros (supra n 10), at para 27, where the Court clarifies that such motives 'cannot, in itself, constitute an abuse of the right of establishment'.

${ }^{15}$ See e.g. Rickford, supra n 6, 1248; Armour, supra n 1; W Bratton, J McCahery, and E Vermeulen, 'How Does Corporate Mobility Affect Lawmaking? A Comparative Analysis' (2009) 54 American Journal of Comparative Law 347; Menjucq, supra n 2, 124; J Armour and WG Ringe, 'European Company Law 19992010: Renaissance and Crisis' (2011) 48 Common Market Law Review 125.
} 
relying on the Treaty freedoms) as an abuse, the Court made clear that the freedom of establishment is (at least also) meant to permit exactly that. ${ }^{16}$

Since a significant - and growing - number of Member States do not require a 'factual link' between their territory and companies formed under its laws, ${ }^{17}$ entrepreneurs from across Europe can now choose from among these laws, no matter where the majority (or indeed all) of its business activities will take place. In other words, Member State cannot require the use of corporations formed under its law for business activities in its territory, as long as some Member States allow the formation of 'letter-box companies'. ${ }^{18}$

Until relatively recently, however, the resulting choice of law was, in practice, primarily of interest for small, newly formed start-up firms, since a number of obstacles made re-incorporation difficult for established firms. ${ }^{19}$ Due to their structure, ${ }^{20}$ newly established companies do not usually have a particular demand for highly sophisticated company law solutions, and consequently choice of law was mainly driven by factors such as minimum capital requirements, basic formation costs, and the speediness of the incorporation process. ${ }^{21}$ This does not mean, however, that the Centros line of cases has been irrelevant for larger, established undertakings: it significantly increased the flexibility of corporate groups with regard to their legal structure, as it also protected the status of local subsidiaries irrespective of the location of their effective management, ${ }^{22}$ and moreover had implications for corporate taxation. The importance of the Establishment chapter for larger, established businesses is likely to further increase as a consequence of developments in both the case law and EU secondary law. First, the Court of Justice has now made it clear that the freedom of establishment also confers on established firms a right to change the law that governs its internal

\footnotetext{
16 See Rickford, ibid at 1248.

${ }^{17}$ Apart from a 'registered office', which is little more than a postal address. The term 'registered office' is thus often being used as being synonymous to the 'incorporation seat' in the sense that it highlights the jurisdiction under whose laws the company has been formed. See e.g. European Commission, Consultation on the cross-border transfers of registered offices of companies (2013), available at http://ec.europa.eu/internal market/consultations/2013/seat-transfer/docs/consultationdocument en.pdf.

18 I.e. companies with no business activity and no permanent establishment in the jurisdiction under whose law they are formed, such that the only connection with their incorporation jurisdiction consists of their business address (registered office). See e.g. M Garcia-Riestra, 'The Transfer of Seat of the European Company v Free Establishment Case-Law' (2004) 15 European Business Law Review 1295, 1300; Rickford, supra $\mathrm{n} 6$.

${ }^{19}$ See e.g. Armour, supra n 1; Bratton and others, supra n 15.

${ }^{20}$ Especially shareholder structure; most start-ups will have only few shareholders.

${ }^{21}$ See e.g. W-G Ringe, 'Corporate Mobility in the European Union - a Flash in the Pan? An Empirical Study on the Success of Lawmaking and Regulatory Competition' (2013) 10 European Company and Financial Law Review 230; Bratton and others (supra n 15), 348; Armour, supra n 1, 385; L Enriques, 'EC Company Law Directives and Regulations: How Trivial Are They?' (2006) 27 University of Pennsylvanid Journal of International Economic Law 1.

${ }^{22}$ I.e. as long as the state of incorporation does not restrict the choice of the corporate headquarters; see Case C-210/06 Cartesio Oktató és Srolgáltató bt. [2008] ECR I-9641.
} 
organisation by either merging with companies incorporated abroad 23 or by reincorporating in another jurisdiction ${ }^{24}$ with legal continuity. Moreover, both the European Company Statute ${ }^{25}$ and the Cross-Border Merger Directive ${ }^{26}$ increase the ease with which companies can subject themselves to another Member State's law, albeit in the former case only if the process coincides with a physical relocation of the company's headquarters. ${ }^{27}$ Recently, the European Commission has revived the $14^{\text {th }}$ Directive ${ }^{28}$ on the reincorporation of existing companies $-\mathrm{a}$ project it had abandoned in 200729 - after the European Parliament requested that issue to be addressed by a Directive because it considered the case law on this matter to have left open too many questions. 30

Taken together, the developments described above are likely to profoundly change the European corporate landscape over the coming years. A number of pathways make choice of company law rules available to both entrepreneurs (incorporators) and established firms throughout the EU, which adds opportunities for regulatory arbitrage - the ability to subject the same economic structure to one of a variety of different sets of legal rules, each with its benefits and costs, in order to reduce costs or increase profits by benefitting from the most (privately) advantageous regulatory treatment without changing the economic substance of the transaction. ${ }^{31}$

It is not our aim to assess the costs and benefits of regulatory arbitrage in European company law. Much has been said about how regulatory arbitrage in company law may affect the European corporate landscape, the likelihood of the

23 C-411/03 SEVTC Sytems AG v Amtsgericht Neunied [2005] ECR I-10805. While the Court made it clear in SEVIC that cross-border mergers fall under the Treaty freedoms and thus have to be made available to European firms irrespective of specific or harmonising legislation, many practical questions remained open, making this route unfeasible or impracticable for most established companies in the EU; see e.g. Hopt (supra n 4), a 18-19.

24 See Case C-210/06 Cartesio, n 22 above, at para 110-112; Case C-378/10 VALE Épitési kft [2012] ECR I-0000, decided 12.7.2012. See e.g. JL Hansen, 'The Vale Decision and the Court's Case Law on the Nationality of Companies' (2013) 10 European Company and Financial Law Review.

25 Council Regulation (EC) No 2157/2001 of 8 October 2001 on the Statute for a European company (SE) OJ L 294/1. See e.g. H Eidenmüller, A Engert, and L Hornuf, 'Incorporating under European Law: The Societas Europaea as a Vehicle for Legal Arbitrage' (2009) 10 European Business Organization Law Review 1.

26 Directive 2005/56/EC of the European Parliament and of the Council of 26 October 2005 on crossborder mergers of limited liability companies, OJ L 310/1.

27 See Article 8 of the SE Statute (supra n 25). For a discussion of this requirement see Ringe, supra $\mathrm{n} 12$, who questions its compatibility with Article 49 TFEU (but see Case C-210/06 Cartesio, n 22 above).

28 See Pubic Consultation on the cross-border transfers of registered offices of companies, $\mathrm{n} 17$ above.

${ }^{29}$ On this see M Wyckaert and F Jenne, 'Corporate Mobility' in K Geens and KJ Hopt (eds), The European Company Law Action Plan Revisited: Reassessment of the 2003 Priorities of the European Commission (Leuven, Leuven University Press 2011) 298; J Rickford, 'Free Movement of Capital and Protectionism after Volkswagen and Viking Line' (2009) in M Tison and others (eds), supra n 2, at 62.

${ }^{30}$ European Parliament resolution of 2 February 2012 with recommendations to the Commission on a 14th company law directive on the cross-border transfer of company seats, 2011/2046(INI). The resolution contains detailed "instructions", essentially asking the Commission to replicate the mechanisms of the Cross-Border Merger Directive (supra n 26).

31 See for a general definition e.g. F Partnoy, 'Financial Derivatives and the Costs of Regulatory Arbitrage' (1997) 22 Journal of Corporation Law 211, 227; V Fleischer, 'Regulatory Arbitrage' (2010) 89 Texas Law Review 227, 229. 
creation of a 'European Delaware', 32 the possible impact of regulatory arbitrage on Member States' rule-making and regulatory competition, ${ }^{33}$ as well as the relationship between capital and labour, ${ }^{34}$ the costs and benefits of experimentation and specialisation by legislators, the ability of the law-maker to accommodate the idiosyncrasies of particular market participants, or the effect regulatory competition has on the quality of legal rules. Our aim is much more modest. Rather than questioning whether a system of company law choice has or will have positive or negative effects as such, we merely want to examine how the interaction of legal rules across different areas of law and across different jurisdictions may create problems where companies are permitted to choose the applicable (company) law. The problems we discuss here are likely to exist in a wide variety of circumstances, but the regulation of companies in the vicinity of insolvency seems to provide a particularly suitable showcase to draw attention to the legal issues at play.

\section{Mutual Recognition, Home State Control, AND HARMONISATION OF COMPANY LAWS}

Before delving into the different areas of law affecting a company in the vicinity of insolvency, we must examine the theoretical backdrop against which the Court has developed its interpretation of the freedom of establishment and its relationship with corporate mobility. Clearly the Centros-line of cases $^{35}$ allocates regulatory power between Member States; for the large (and ill-defined) area of company law, it does so in favour of the Member State initially granting legal status to a corporation, irrespective of 'economic realities' - i.e. largely ignoring the nature of the factual ties between a company's business and the national economies of the Member States.

When analysing the implications of EU law for the private international law in this area, two issues are worth highlighting. First, company law constitutes the legal framework according to which most private economic activity is carried out in market economies, and there can thus be little doubt that a clear and predictable allocation of rule-making powers between different interested (i.e. affected) Member States is an important prerequisite for the functioning of the single market. Without an allocation of some sort companies operating across borders would be subject to multiple, potentially conflicting and perhaps unpredictable legal

\footnotetext{
${ }^{32}$ E.g. Armour, supra n 1; L Enriques, 'EC Company Law and the Fears of a European Delaware' (2004]) European Business Law Review 1259; S Lombardo, 'Regulatory Competition in Company Law in the European Union after Cartesio' (2009) 10 European Business Organization Law Review 627; Bratton and others (supran 15).

${ }^{33}$ E.g. Bratton and others (supra n 15); A Johnston and P Syrpis, 'Regulatory Competition in European Company Law after Cartesio' (2009) 34 European Law Review 378.

${ }^{34} \mathrm{M}$ Gelter, 'Tilting the Balance between Capital and Labor? The Effects of Regulatory Arbitrage in European Corporate Law on Employees' (2010) 33 Fordham International Law Journal 792.

${ }^{35}$ See text to $n 8-16$.
} 
obligations. But this does not necessarily assist us in answering which 'rule-making rule' is likely to create the best outcomes, and there are of course various possible candidates. Second, a distinction has to be made between an allocation of rulemaking powers intended to merely avoid costly duplication of regulatory efforts on the one hand, and solutions which go further by designating one single Member State to decide all matters arising within a particular regulatory space on the other hand.

These two issues are also (loosely) related to the familiar 'mutual recognition' and 'home state control' approaches. ${ }^{36}$ The former approach, by aiming at avoidance of regulatory redundancies, focusses on preventing Member States from ignoring the regulatory framework an entity is subject to due to its connection with other Member States. The impact of such an approach to defining Member States' regulatory competences is rather limited, as it would suggest that Member States are only prevented from enforcing unnecessary rules - i.e. rules the aims of which have already been achieved by other means. In other words, a pure mutual recognition approach primarily mandates an appreciation of the relevant 'regulatory history' before imposing legal requirements for (in our case) companies with cross-border operations. ${ }^{37}$ Any such approach is of course based on a notion of equivalence between the different legal systems involved. A meaningful 'duplication' can only exist where one presumes that the relevant jurisdictions are all able and willing to give effect to the rules in question, and only this equivalence justifies prioritising one jurisdiction over the other when defining the regulatory spaces occupied by different Member States. To be sure, this is not to say that all jurisdictions involved are necessarily equally well-suited to address the questions at issue. In fact, one would expect that the allocation of regulatory power will be informed by a notion of who the best-suited regulator would likely be in a given context, although views on this question are bound to differ across Member States. The point is, rather, that this approach prevents Member States from generally presuming the necessity to substitute or supplement foreign regulatory solutions with domestic ones.

As such an approach aims only at preventing duplication of regulatory burdens, it ultimately depends on an acknowledgement that a particular legal problem or social conflict is in fact also being addressed by another Member State. Absent that, an (exclusive) allocation of regulatory powers cannot be explained by a desire to avoid 'double jeopardy'. Take for example a rule requiring company directors to pay due regard to the environmental impact of the company's operations existing in one Member State. To the extent that no other interested Member State adopts rules of similar effect, even a wide 'outreach' application of this rule would not lead to a duplication of the regulatory burden of companies subject to the rule. To be sure, the very question of whether or not a particular rule results in a relevant duplication of regulatory efforts will often be a

\footnotetext{
36 See KA Armstrong, 'Mutual Recognition' in C Barnard and J Scott (eds), The Law of the Single Market: Unpacking the Premises (Oxford, Hart, 2002), 225, especially at 230.

${ }^{37}$ See Armstrong (ibid at 234).
} 
controversial one. One may, for instance, take different views on whether the application of a duty of company directors to pay due regard to an undertaking's environmental impact in Member State A operates in much the same way as concurrently applicable stricter direct environmental protection laws in Member State B, or whether minimum capital requirements in Member State A and stricter distribution rules in Member State B create a 'double jeopardy'-situation when applied cumulatively. Nevertheless, following the double jeopardy-logic would mean that it is the answer to this 'double jeopardy'-question that determines the regulatory reach of the jurisdictions involved.

Under the alternative approach - pure home state control - regulatory power would be directly and exclusively allocated between the 'interested' Member States, e.g. in favour of the jurisdiction which has first granted market access ${ }^{38}$ or, in the case of companies, the law of the Member State under which the company has initially been formed. Unlike the mutual recognition approach, true home state control - or a competitive regulatory model ${ }^{39}$ - reaches beyond the problem of duplicity of regulatory compliance. Instead of only seeking to avoid a situation where EU nationals are burdened by multiple different regulatory requirements that all pursue a common policy goal, home state control also, in principle, covers situations where Member States disagree on these very policy goals, rather than just the best path to achieve them.

Both approaches cannot be viewed in isolation from the harmonisation of laws, and particularly so in the area of company law. First, both approaches can operate as alternatives to the harmonisation of laws. ${ }^{40}$ Rather than harmonising regulatory requirements, cross-border activity can be facilitated within a fairly diverse regulatory environment, provided that compliance with the legal requirements of one (i.e. the home state) system replaces the requirements to comply with similar rules of another (i.e. the host state) legal system. Second, the relevance of mutual recognition depends on equivalence and similarity of the relevant legal frameworks: Where legal systems differ too much, a strategy of the mutual recognition type would likely fail to lower the cost of cross-border activity simply because the home state requirements that have been complied with do not address the same issues as the rules of the host state legal order, which means that engaging in cross-border activity increases the regulatory burden, even if the additional rules do not duplicate the already existing requirements of the home jurisdiction, as can be seen in our example above. Thus, the approach we labelled 'mutual recognition' is likely to be of little use in practice for facilitating crossborder economic activity unless a certain level of harmonisation of substantive laws (or at least close alignment of policy goals) exists. ${ }^{41}$ The home state control-

${ }^{38}$ See ibid at 228.

39 MP Maduro, We the Court: The European Court of Justice and the European Economic Constitution (Oxford, Hart, 1998) 126.

40 See Armstrong, supra n 36, 225-226.

41 ibid. 
approach is linked even more intimately with the harmonisation of national laws, or more precisely with the equivalence of such laws. ${ }^{42}$ By accepting the exclusive application of home rules in cross-border situations, the host state effectively signs away its ability to regulate economic activity within its borders, as it necessarily results in economic actors only complying with one set of rules, even where the parallel application of different sets of rules would not result in an unnecessary accumulation of regulatory requirements. Thus, host states - and every Member State is of course also a host state in relation to some economic actors - will typically accept a system of home state control only where the substantive rules across the different jurisdictions are 'similar enough', i.e. where the scope for regulatory arbitrage is diminished by the equivalence of the different sets of rules. ${ }^{43}$

How can we best categorise the approach taken by the Court of Justice in relation to corporate mobility and choice of law? This question cannot yet be answered with certainty, and as will be shown below, Member States seem to take different views on it. Where exactly would the differences lie between a home state control and a mutual recognition model in the area of company law? Clearly, both approaches would result in the home state (i.e. the incorporation jurisdiction) retaining most of the regulatory power over company law, with limited scope for host state control - a result we know to be right in practice based on the jurisprudence of the European Court.

Viewed through the lens of a mutual recognition model, the allocation of regulatory power to the home state would follow from the fact that, naturally, both jurisdictions have to address the same types of problems and social conflicts, such that compliance with both jurisdictions' legal requirements would necessarily involve a costly duplication of regulatory requirements. A pure home state approach would lead to the same result without the intermediate step of testing whether the two jurisdictions indeed address the same problems through their laws. However, where the host state addresses a policy area (say, environmental policy) at least in part through company law rules, ${ }^{44}$ while the state of incorporation employs a different, non-company law technique (e.g. emission trading), what we call the mutual recognition model would suggest that the host state's power to regulate is unaffected: an 'outreach' application of the domestic rules to all companies operating within its territory would not lead to a duplication of regulation. A home state control view, on the other hand, would suggest that the power to regulate company law as such is allocated to the home state, and that perceived 'gaps' in that law - such as the absence of environmental considerations in directors' duties regulation - is irrelevant.

\footnotetext{
42 It is of course the equivalence or similarity of laws that ultimately matters here, but equivalence will typically require harmonisation in most areas of the law.

${ }^{43}$ See on the link between this and the concept of maximum harmonisation Gerner-Beuerle, supra $\mathrm{n} 12$.

${ }^{44}$ E.g. by defining directors' duties with reference to environmental impact.
} 
None of the Centros-line cases ${ }^{45}$ provides a clear answer as to the underlying model. Inspire $A r t^{46}$ may be the most informative case in that it concerned a clear outreach-type statute: Dutch rules applicable to certain foreign-incorporated entities 'intruded' into and interfered with the status-providing home state law (UK law), and the Court held this intrusion to be a (non-justifiable) restriction. However, in that case Dutch law purported to do so in order to protect creditors a concern undoubtedly shared by the UK company law legislator. Thus, the outcome of Inspire Art- and the remaining Centros-line cases - can be explained under both models here presented. Nevertheless, the Court's reasoning, as well as the absence of any meaningful examination of functional equivalence between home and host state rules in the case law, suggests that it indeed is a home state control model that the Court has developed.

There is at least one important case in which the 'underlying model'-question would be highly relevant: board-level employee participation. Except following a cross-border merger or an SE-formation, employee participation rules are currently applied on an incorporation basis only, and no significant attempt has been made to our knowledge by any Member State to apply its employee participation rules to foreign-incorporated companies. But what if, say, Germany adopted such a law, for instance mandating employee representatives on boards of foreign companies with significant (or exclusively) German operations? It is submitted that an assessment of such a (hypothetical) rule would differ depending on the underlying model, being permissible under a mutual recognition view, but in need of Gebhard-justification ${ }^{47}$ under a home state control model. The latter outcome, arguably, seems more likely.

It is also worth pointing out that both models are necessarily based on implicit "presumptions of equivalence," 48 although these presumptions differ somewhat depending on the fundament one suspects beneath the Court's case law. Most obviously, a home state control approach must be based on the presumption that the Member State allocated with regulatory power in a particular area of law will be willing and able to create a legal framework that is, in general terms, acceptable to other Member States. But even a mutual recognition model must be predicated on the presumption of broad equivalence regarding the efficacy of the legal systems involved, which justifies that broad, indistinctly applicable host state measures duplicating home state requirements constitute a prima facie breach. ${ }^{49}$ The implied

\footnotetext{
45 supra n 10.

46 supra $\mathrm{n} 14$

47 See Case C-55/94 Gebhard v Consiglio dell'Ordine degli Avvocati e Procuratori di Milano [1995] ECR I-4165, which requires restrictions to be non-discriminatory, suitable to achieve an overriding public interest objective, proportionate, and not go beyond what is necessary to achieve the objective in question.

48 See on the link to mutual recognition, e.g., C Barnard, The Substantive Law of the EU: The Four Freedoms (Oxford University Press, 2nd edn, 2007) 111; see also A Rosas, 'Life after Dassonville and Cassis: Evolution but no Revolution' in MP Maduro and L Azoulai (eds) The Past and Future of EU law: The Classics of EU Law Revisited on the 50th Anniversary of the Rome Treaty (Oxford, Hart, 2010), 433, 440.

49 See e.g. Centros (supra n 10).
} 
presumptions of equivalence are of course an expression of the set of common principles across Member States, and perhaps ultimately an expectation that Member States have an interest in creating appropriate national company law systems that avoid externalities, which explains the high bar set by the Gebhard test.

Company law is in some ways 'special': its rules are necessarily highly interlinked and interdependent, and they do not lend themselves easily to be selectively replaced by 'foreign law'. In fact, the two competing conflict of laws approaches, the real seat and the incorporation doctrine, have in common that they both aim at leaving intact what is generally a coherent set of interwoven rules. ${ }^{50}$ The incorporation doctrine achieves this, in principle, by applying the home state legal system in relation to most questions of company law, no matter how closely connected a company is to another jurisdiction. ${ }^{51}$ The real seat doctrine, on the other hand, 'leaves intact' the home state legal system - i.e. accepts that the foreign company will be governed by home state law - but does so only up to a certain point - typically the point is where the centre of management and control is located in the jurisdiction applying the real seat doctrine. Where the intensity of connection with the real seat state exceeds this trigger, the real seat jurisdiction will then apply its entire company law to the foreign entity. In both cases, the combination of company laws and the relevant conflict of laws rules ensure that companies are subject to a coherent, compatible and typically well thought-through legal framework in relation to most aspects of their internal organisation, including their relationship with investors. The special status of company law, and the "one law"-result achieved by both of the traditional approaches to allocate rule-making powers across Member States in company law matters, may also support a home state control-approach view of the Court's case law.

Problems do arise, however, whenever company law rules interact with other areas of law or with the institutional framework offered by a particular

\footnotetext{
50 The aim to agree on a private international law framework for companies which not only achieves consistent results across jurisdictions, but which also renders only one national law applicable to all aspects of a company's life has been an integral part of the international efforts in this field; see e.g. the ILA Draft Convention on Conflicts of Law relating to Companies, International Company Law Report (1958) 48 Int'l L. Ass'n Rep. Conf. 629, 645 (Art 3 and 4). This question has also been raised in the US, where corporate law is a matter of State regulation; the Supreme Court has emphasised the importance of a 'single law' solution (see Edgar v. MITE Corp., 457 U.S. at 645: 'the internal affairs doctrine is a conflict of laws principle which recognizes that only one State should have the authority to regulate a corporation's internal affairs - matters peculiar to the relationships among or between the corporation and its current officers, directors, and shareholders - because otherwise a corporation could be faced with conflicting demands' (emphases added)). Similarly, the Delaware Supreme Court in VantagePoint (VantagePoint Venture Partners 1996 v. Examen, Inc., 871 A.2d 1108 (Del. 2005)) refused to apply a Californian law purporting to regulate the internal affairs of certain Delaware corporations; see C Allmendinger, 'Company Law in the European Union and the United States: A Comparative Analysis of the Impact of the EU Freedoms of Establishment and Capital and the U.S. Interstate Commerce Clause' (2013) 4 William \& Mary Business Law Review 67, 83. See also P Kindler, 'Internationales Handels- und Gesellschaftsrecht', in FJ Säckerand and R Rixecker (eds), Münchener Kommentar zum Bürgerlichen Gesetzbuch (Munich, CH Beck, 5th edn, 2010, Vol 11), at 321, emphasising the fact that functional interdependence of company law rules necessitates the applicability of one single law. 51 See on the two different theories e.g. Menjucq, supra n 2; Armour and Ringe, supra $\mathrm{n} 15$.
} 
jurisdiction. ${ }^{52}$ This can be true throughout the life of a company, of course: capital maintenance rules may interact with accounting regulation; company law may implicitly or explicitly rely on the existence of notaries to afford protection to shareholders and third parties; the liability of company directors may depend on their status under the applicable labour law; the exercise of voting rights may be restrained by concepts of general civil law. Accordingly, the operation of company law may change once the company 'leaves' its home jurisdiction - at least to the extent that by doing so, it severs the connection between the company law it is subject to and the rules that interact - and were meant to interact - with it.

One situation where 'inter-doctrinal' interaction becomes particularly important, it is submitted, is where a company approaches insolvency. While, as we shall see, all Member States implement legal strategies to address the various problems connected to this stage of a company's life, the legal techniques used differ widely. More importantly, these legal strategies are 'located' in areas of law the application of which depends on connecting factors different from what determines the application of the company law rules they interact with.

\section{FUNCTIONALITY AND INTERNATIONAL SCOPE OF CREDITOR PROTECTION LAW}

\section{Legal Strategies to Protect Creditors in the Vicinity of INSOLVENCY}

As a company nears insolvency and the equity capital evaporates, perverse incentives are created for shareholders and directors alike. ${ }^{53}$ Creditors, rather than shareholders are now rightly to be seen as residual claimants. ${ }^{54}$ At this point, shareholders (and directors) have privately optimal risk-levels for the company's business operation that would render it inefficient to leave them 'in charge' without regulatory intervention. ${ }^{5}$ Virtually all legal systems have developed strategies to address this problem and to avoid inefficient risk-shifting in the vicinity, or upon occurrence, of insolvency.

\footnotetext{
52 This is of course the very problem discussed in relation to all 'legal transplants'; see infra Section D.2. The problem can even arise within a given jurisdiction; see e.g. E Rock and M Wachter, 'Dangerous Liaisons: Corporate Law, Trust Law, and Interdoctrinal Legal Transplants' 96 Nortbwestern University Law Review 651.

${ }^{53}$ See e.g. PL Davies, 'Directors' Creditor-Regarding Duties in Respect of Trading Decisions Taken in the Vicinity of Insolvency' (2006) 7 European Business Organization Law Review 301; H Eidenmüller, 'Trading in Times of Crisis: Formal Insolvency Proceedings, Workouts and the Incentives for Shareholders/Managers' (2006) 7 European Business Organization Law Review 239; T Bachner, 'Wrongful Trading - A New European Model for Creditor Protection?' (2004) 5 European Business Organization Lam Review 293.

${ }^{54}$ Davies, ibid at 324.

${ }^{55}$ See the detailed analysis by Eidenmüller, supra $\mathrm{n} 53$.
} 
In the EU, the main strategies are: (1) a duty of the company directors to file for the opening of insolvency proceedings; (2) liability of the directors for wrongful trading, i.e. the continuation of trading even though 'there was no reasonable prospect that the company would avoid going into insolvent liquidation';56 (3) a change of directors' fiduciary duties; and (4) the duty to call a general meeting and either recapitalise or liquidate the company. These strategies are supplemented by general principles of company law or civil and commercial law. The general duties of directors continue to apply in the vicinity of insolvency. For example, directors may be held liable for a breach of the duty of care by managing the company imprudently and thus causing or aggravating the company's insolvency. Some jurisdictions take recourse to tort law to hold directors responsible for a loss suffered by the creditors. Finally, in addition to civil liability, administrative and/or criminal sanctions apply to directors who fail to file for the opening of insolvency proceedings in violation of legal requirements or display other types of misconduct. An important administrative sanction is the disqualification of directors, which may be ordered by the bankruptcy court if the director has been convicted of a crime and, depending on the jurisdiction, if the director has materially violated legal obligations or is 'unfit to be concerned in the management of a company'. ${ }^{7}$

The following table gives an overview of the distribution of the four main strategies in the EU and, for purposes of comparison, the US. ${ }^{58}$

Table 1. Legal strategies in the vicinity of insolvency

\begin{tabular}{|l|l|l|l|}
\hline Country & $\begin{array}{l}\text { Duty to file or } \\
\text { wrongful trading }\end{array}$ & $\begin{array}{l}\text { Change of } \\
\text { duties }\end{array}$ & $\begin{array}{l}\text { Convene or } \\
\text { recapitalise }\end{array}$ \\
\hline Austria & duty to file & no & convene GM \\
\hline Belgium & duty to file & no & convene GM \\
\hline Bulgaria & duty to file & no & recapitalise \\
\hline Croatia & duty to file & no & convene GM \\
\hline Cyprus & wrongful trading & yes & convene GM \\
\hline Czech Republic & duty to file & no & recapitalise \\
\hline Denmark & $\begin{array}{l}\text { hybrid approach } \\
\text { (both) } 59\end{array}$ & yes & convene GM \\
\hline
\end{tabular}

56 UK Insolvency Act 1986, s 214(2)(b).

57 Irish Companies Act 1990, s. 160(2)(d); UK Company Directors Disqualification Act 1986, ss. 6(1), $8(2)$.

58 Adapted from C Gerner-Beuerle, P Paech, and EP Schuster, 'Study on Directors' Duties and Liability' (2013), available at http://ec.europa.eu/internal market/company/docs/board/2013-studyanalysis en.pdf. Note that not all strategies apply equally to private limited companies. 


\begin{tabular}{|c|c|c|c|}
\hline Country & $\begin{array}{l}\text { Duty to file or } \\
\text { wrongful trading }\end{array}$ & $\begin{array}{l}\text { Change of } \\
\text { duties }\end{array}$ & $\begin{array}{l}\text { Convene or } \\
\text { recapitalise }\end{array}$ \\
\hline Estonia & duty to file & yes & recapitalise \\
\hline Finland & duty to file & no & convene GM \\
\hline France & duty to file & no & recapitalise \\
\hline Germany & duty to file & no & convene GM \\
\hline Greece & duty to file & no & convene GM \\
\hline Hungary & duty to file & yes & convene GM \\
\hline Ireland & wrongful trading & yes & convene GM \\
\hline Italy & duty to file & no & recapitalise \\
\hline Latvia & duty to file & yes & recapitalise \\
\hline Lithuania & duty to file & no & recapitalise \\
\hline Luxembourg & duty to file & no & recapitalise \\
\hline Malta & duty to file & yes & convene GM \\
\hline Netherlands & $\begin{array}{l}\text { wrongful trading } \\
\text { prohibition }\end{array}$ & no & convene GM \\
\hline Poland & duty to file & no & convene GM \\
\hline Portugal & duty to file & no & recapitalise \\
\hline Romania & wrongful trading & no & convene GM \\
\hline Slovakia & duty to file & no & convene GM \\
\hline Slovenia & duty to file & no & convene GM \\
\hline Spain & duty to file & no & recapitalise \\
\hline Sweden & duty to file & no & recapitalise \\
\hline $\begin{array}{l}\text { United } \\
\text { Kingdom }\end{array}$ & wrongful trading & yes & convene GM \\
\hline United States & $\begin{array}{l}\text { deepening } \\
\text { insolvency }{ }^{60}\end{array}$ & ambivalent $^{61}$ & $\begin{array}{l}\text { No duty to } \\
\text { convene or }\end{array}$ \\
\hline
\end{tabular}

${ }^{59}$ Case law has established a rule similar to the UK wrongful trading prohibition. Directors who know (or should have known) that the company has no reasonable prospect of avoiding insolvency must minimise the potential losses to creditors or will be liable. In addition, a duty to file for insolvency also applies.

60 The tort of deepening insolvency goes back to Unsecured Creditors v. R.F. Lafferty \& Co., 267 F.3d 340 (3d Cir. 2001) (applying Pennsylvania law). However, it is not recognised as a separate cause of action in Delaware and does not give rise to a duty to liquidate, see Trenwick. America Litigation Trust v. Ernst \& Young, L.L.P., 906 A.2d 168 (Del Ch. 2006). Instead, deepening insolvency claims may be integrated into the general framework of directors' duties, In re The Brown Schools, 386 B.R. 37, 46-47 (Bankr. D. Del. 
As is evident from Table 1, the majority of member states provide for a duty on the part of a company's directors to timely file for insolvency. Typically, this strategy is then buttressed by a consequential liability of directors for any depletion of the company's assets resulting from the delayed insolvency filing. In most Member States employing this strategy, this liability can only be enforced by the liquidator and thus results in a proportional satisfaction of all creditors' claims. The second main strategy is very similar in nature. Instead of setting a legal requirement for the insolvency filing, a jurisdiction may require directors to cease trading at a particular point in time.

The filing strategy is more widely spread. It is necessarily triggered by the insolvency of the company (however defined by national law), rather than merely a threat of insolvency. The 'wrongful trading' strategy will sometimes be triggered only after the company has reached a state of formal balance sheet insolvency, ${ }^{62}$ but may also be triggered before the company is formally insolvent, as it is based on an assessment of the company's financial prospects. Thus, directors of a formally insolvent company that has a realistic chance to trade its way out of its situation may be justified in continuing the business, while directors in a not-yet insolvent company may be obliged to cease its operations where the avoidance of a (future) insolvency seems highly unlikely. Of course, jurisdictions following the 'duty to file'-strategy will also often allow the continuation of trading beyond the point where the company is balance-sheet insolvent, ${ }^{63}$ but they will do so by adjusting the definition of the insolvency grounds, rather than by adjusting the duty to file itself.

In addition, in some Member States the definition or the scope of directors' duties changes as the company approaches insolvency, particularly by moving from a shareholder-centric towards a more creditor-regarding set of objectives, ${ }^{64}$ or by changes in the general standard of care. ${ }^{65}$

An additional regulatory strategy that at least indirectly addresses the problems posed by companies in the vicinity of insolvency is the so-called "re-capitalise or liquidate" rule. Throughout the EU, public companies are obliged to call a general meeting where the (cumulated) losses of a company exceed $50 \%$ of the subscribed capital. ${ }^{6}$ While the Second Directive requires the calling of a general meeting in

2008). For a discussion see CW Frost, Corporate Governance in insolvency and Bankruptcy (San Francisco, LexisNexis, 2011), \$3[4].

${ }^{61}$ Delaware courts initially allowed the directors to rely on the interests of the creditors as a 'shield' in order to rebut a breach of duty claim brought by the shareholders, Credit Lyonnais Bank Nederland, N.V.v. Pathe Communications Corporation, 1991 W.L. 277613 (Del. Ch.). In recent decisions, the Delaware courts, however, emphasised that the content of the duties of directors and the constituencies to whom they are owed do not fundamentally change in the vicinity of insolvency. See, for example, North American Catholic Educational Programming Foundation, Inc. v. Gheewalla, 930 A.2d 92 (Del. Supr. 2007) (holding that 'in the zone of insolvency, the focus for Delaware directors does not change: directors must continue to discharge their fiduciary duties to the corporation and its shareholders by exercising their business judgment in the best interests of the corporation for the benefit of its shareholder owners'. Ibid, 101).

${ }^{62}$ See e.g. Davies, supra n 53, 311; Bachner, supra n 53.

${ }^{63}$ See the comparison of German and English law by Bachner, supra $\mathrm{n} 53$.

${ }^{64}$ See e.g. Davies, supra n 53, at 327-329.

65 This seems to be the case in relation to Denmark.

${ }^{66}$ See Art 17 of the Second Council Directive 77/91/EEC of 13 December 1976, OJ L 26/1. 
these circumstances, it does not actually require companies to take any specific action. In so far as Art 17 of the Second Directive only requires a meeting of the shareholders, the rule does not seem to follow a clear economic rationale. First, the reference to the subscribed capital is, in itself, not a meaningful triggering event. The registered share capital will not be a particularly useful reference point, as this figure says virtually nothing about the assets or capital needs of a company. ${ }^{67}$ Second, even (or particularly) where the event of losses amounting to more than $50 \%$ of the registered share capital is a significant point in time in the company's life, it is at the very least questionable whether this is the right time to put shareholders in the driver's seat given the perverse incentives that exist at this point. ${ }^{68}$ In fact, to the extent that this event coincides with the company becoming significantly undercapitalised, shareholders' incentives are distorted, since limited liability will often mean that an increase in the company's risk profile also leads to an increase in the value of their shares.

While a majority of the Member States have implemented Art 17 of the Second Directive as a mere duty to call a meeting, some go beyond this minimum requirement. These Member States require companies to choose, upon a loss of half of their subscribed share capital, between either re-capitalising the company or winding down its operations and liquidating the company. The effect of the 'recapitalise or liquidate' rule on near-insolvency trading is twofold. First, it aims at making it less likely for companies to trade in a state of capital depletion, at least where the nominal share capital is indeed a significant figure. Second, duty-related enforcement mechanisms are directly linked to this strategy, as failure to ensure that appropriate capital measures are taken at this very early stage typically leads to the liability of the directors. In fact, it may well be the case that it is the relative ease with which non-compliance with this rule can be proven, as compared to e.g. incompetent management or foreseeability of insolvency, which makes this strategy attractive despite the arbitrary nature of its trigger.

\section{EU Private INTERNATIONAL LaW Framework}

The principle of home state control, as we understand it here, attempts to avoid friction between legal systems and the imposition of double burdens on market participants that engage in cross-border economic activity by allocating comprehensive regulatory authority to one Member State, the home state. However, whether a social conflict is comprehensively regulated by one legal system depends not only on the existence of a rule, usually stemming from European law, that performs this allocative function unambiguously and to the exclusion of regulatory action by other Member States, but also on the coherence

${ }^{67}$ See J Rickford, 'Reforming Capital: Report of the Interdisciplinary Group on Capital Maintenance' (2004) 15 European Business Law Review 919; J Armour, 'Legal Capital: an Outdated Concept?' (2006) 7 European Business Organization Law Review 5.

${ }^{68}$ See Davies, supra n 53. 
of the home state's legal system. In domestic situations, a legal system is necessarily coherent in that the solution to the social conflict will be derived from the body of rules constituting the legal system. In cross-border situations, on the other hand, the home state's private international law determines whether, and if yes, which parts of the home state's substantive law are applicable to the case at hand. Thus, the goal of home state control may be undermined by a dissection of regulatory authority at the second stage of the investigation, with potentially detrimental consequences for mobility within the single market.

The conflict rules that determine the law applicable to European companies with cross-border operations are partly harmonised and contained in a number of EU regulations, and partly derive from national law. The most likely sources of the legal strategies discussed above that are employed to address disputes in the vicinity of insolvency are a country's insolvency law, company law, and tort law. We will examine the conflict rules in these areas in turn in order to sketch the private international law framework that governs vicinity of insolvency situations and assess the extent to which it leads, in appropriate situations, to a dissection of regulatory authority.

\section{Insolvency law}

The rules on jurisdiction for opening insolvency proceedings, recognition of judgments delivered on the basis of such proceedings, and the applicable law have been unified by the EU Insolvency Regulation. ${ }^{99}$ The main connecting factor, both for jurisdiction and applicable law, is the centre of a debtor's main interest (COMI). The courts of the Member State in whose territory the COMI is located have international jurisdiction to open insolvency proceedings. ${ }^{70} \mathrm{COMI}$ is a rather ambiguous criterion that has given rise to a substantial body of case law and received much attention in the academic literature. ${ }^{71} \mathrm{It}$ is not necessary to review the debate in this article; a brief description of the concept shall suffice. According to the Regulation, the centre of main interest corresponds 'to the place where the debtor conducts the administration of his interests on a regular basis', ${ }^{72}$ which has been interpreted by national courts as referring to the place where the 'head office functions' of the company are performed..$^{73}$ In the case of a legal person, COMI is presumed to be at the place where the person's registered office is located. ${ }^{74}$ The presumption can be rebutted if factors which are both objective and ascertainable by third parties enable it to be established that an actual situation exists which is

\footnotetext{
${ }^{69}$ Council regulation (EC) No 1346/2000 of 29 May 2000 on insolvency proceedings [2000] OJ L160/1.

${ }^{70}$ Insolvency Regulation, art 3(1).

${ }^{71}$ For a detailed discussion with references see G Moss, IF Fletcher, and S Isaacs (eds), The EC Regulation on Insolvency Proceedings (Oxford University Press, 2nd edn, 2009), 3.11-3.15, 8.72-8.99. The leading decision of the Court of Justice is Case C-341/04 Eurofood IFSC Ltd. [2006] ECR I-3813.

72 Insolvency Regulation, Recital 13. The Proposal for a Regulation of the European Parliament and of the Council amending Council Regulation (EC) No 1346/2000 on insolvency proceedings, COM(2012) 744 final, moves the definition of the COMI from the recitals to the main text, see art 3(1), as amended.

${ }^{73}$ For a discussion of the case law see Moss et al, supra n 71, 8.81-8.87.

${ }^{74}$ Insolvency Regulation, art 3(1).
} 
different from [the presumption]', 75 in particular where the company does not carry out any business activities in the incorporation state. ${ }^{76}$ Thus, the connecting factor under the Insolvency Regulation incorporates both elements of the incorporation theory and the real seat theory in private international company law. COMI, at least as understood by the 'head office functions' test, corresponds largely to the siège reel of the company. ${ }^{77}$ Given that the 'head office functions' test is relevant (albeit not sufficient) for a rebuttal of the presumption and that it is conclusive where the management functions of the company are performed in the place of registration, ${ }^{78}$ it is justified to argue that the Insolvency Regulation is predominantly drafted in the spirit of the real seat theory. ${ }^{79}$

The reach of the Insolvency Regulation is almost as controversial as the meaning of COMI. One of the objectives of the Insolvency Regulation is the reduction of forum shopping by financially distressed and insolvent firms. ${ }^{80}$ The Regulation aims to achieve this goal not only by defining COMI so as to render it resistant to manipulation, but also by providing for a clear delimitation of the reach of COMI as a connecting factor to avoid regulatory gaps (or the accumulation of legal rules). However, as will be shown below, for two reasons it is questionable whether the Regulation meets this objective. First, the provisions that determine the scope of the Regulation are ambivalent, and second, the boundaries of private international insolvency law are drawn by the Regulation in a formalistic way that does not appreciate the underlying social conflicts.

COMI determines jurisdiction for the collective insolvency proceedings listed in Annex A to the Regulation, ${ }^{81}$ as well as 'actions which derive directly from those proceedings and which are closely connected to them'. 82 The Court of Justice interprets the latter requirements restrictively. An action is likely to be qualified as 'directly deriving' from insolvency proceedings and as being 'closely connected' with them if it requires the opening of insolvency proceedings or the

75 Eurofood, supra n 71, para 34. Under the proposal for an amended Insolvency Regulation, the presumption is unrebuttable if 'the bodies responsible for the management and supervision of a company are in the same place as its registered office and the management decisions are taken there in a manner ascertainable by third parties' (codifying Case C-396/09 Interedil Srl, in liquidation v Fallimento Interedil Srl and Intesa Gestione Crediti SpA, nyr, para 50). Thus, the 'head office functions' test will be the sole factor if the registered seat coincides with the place where the head office functions are performed.

${ }^{76}$ Eurofood, supra n 71, para 35.

${ }^{77}$ G McCormack, 'Reconstructing European Insolvency Law - Putting in Place a New Paradigm' (2010)

30 Legal Studies 126, 129

78 Interedil, supra n 75 , para 50.

79 IF Fletcher, Insolvency in Private International Law: National and International Approaches (Oxford University Press, 2nd edn, 2005), 7.42.

${ }^{80}$ Insolvency Regulation, Recital 4.

${ }^{81}$ Insolvency Regulation, arts 1(1), 2(a).

82 Case C-339/07 Christopher Seagon v Deko Marty Belgium NV [2009] ECR I-767, para 21 (dealing with an avoidance action pursuant to the German Insolvency Code, s 129). This construction of art 3(1) of the Insolvency Regulation relies on the case law of the Court of Justice regarding what is now the bankruptcy exception in art 1(2)(b) of the EU Judgments Regulation (Council Regulation (EC) No 44/2001 of 22 December 2000 on jurisdiction and the recognition and enforcement of judgments in civil and commercial matters [2001] OJ L12/1), see in particular Case 133/78 Gourdain v Nadler [1979] ECR 733. 
involvement of a liquidator ${ }^{83}$ and the action aims at protecting 'the general body of creditors' ${ }^{84}$ These conditions were held to be satisfied for avoidance actions, ${ }^{85}$ liability for the failure to file for the opening of insolvency proceedings, $86 \mathrm{UK}$ wrongful or fraudulent trading, ${ }^{87}$ the French action en comblement de passif, now action en responsabilité pour insufissance d'actif, 88 and actions regarding shareholder loans given, or not called in, when the company nears insolvency, ${ }^{89}$ but not for claims against directors for a breach of duty. ${ }^{90}$ It should be noted, however, that many questions remain controversial in the Member States. ${ }^{91}$

The applicable law generally follows the rules on international jurisdiction, i.e. the court of the opening of the insolvency proceedings applies the lex fori as lex concursus. 92 The lex concursus determines the conditions for the opening of the proceedings, their conduct, closure, and effects. ${ }^{93}$ The Regulation specifies the content of the general rule by providing for a non-exhaustive list of matters that are governed by the lex concursus. ${ }^{94}$ The list does not include the above-mentioned issues, for example the liability of directors for wrongful trading, responsabilite pour insufissance d'actif, or responsabilidad concursal. ${ }^{95}$ However, such issues fall within the scope of the Regulation's general conflict rule if they are closely related to the

83 Case C-292/08 German Graphics Graphische Maschinen GmbH v Alice van der Schee [2009] ECR I-8421, para 32 (holding that the enforcement of a retention of title clause by a creditor against the insolvent company falls outside the scope of the Insolvency Regulation because "the mere fact that the liquidator is a party to the proceedings is not sufficient to classify the proceedings $[\ldots]$ as $[\ldots]$ deriving directly from the insolvency and being closely linked to proceedings for realising assets", para 33). See also the VirgosSchmit Report on the Convention on Insolvency Proceedings (1996), para 196 (explaining that 'actions that the debtor could have undertaken even without the opening of insolvency proceedings' should not be included, but only actions 'which are based on (and not only affected by) insolvency law and are only possible during the insolvency proceedings or in direct relation with them').

${ }^{84}$ Deko Marty, supra n 82, para 16.

85 Ibid. See also Byers v Yacbt Bull Corp [2010] EWHC 133 (Ch) (holding that an action to set aside an undervalue transaction pursuant to the UK Insolvency Act 1986, s 238, falls within the bankruptcy exception of the Judgments Regulation).

${ }^{86}$ See, e.g., LG Kiel [District Court Kiel, Germany], NZG 2006, 672 (classifying the duty to file and ensuing liability pursuant to the German Civil Code, s 823(2), and the Stock Corporation Act, s 93(2), as insolvency law, and applying the provisions to an English limited company with COMI in Germany).

87 Oakley v Ultra Vehicle Design Ltd [2006] BCC 57, para 42.

88 Art L.651-2 of the French Commercial Code. See Gourdain, supra n 82.

${ }^{99}$ BGH [German Federal Court of Justice], judgment of 21 July 2011, IX ZR 185/10 (holding that the recharacterisation of shareholder loans as equity in the vicinity of insolvency should be classified as insolvency law, even though the doctrine originated in capital maintenance law (analogy to German Limited Liability Companies Act, ss 30, 31, version in force until 31 October 2008, now codified in the German Insolvency Code, ss 39, 135)).

${ }^{90}$ Grupo Torras SA v Sheikh Fabad Mohammad Al-Sabah [1995] 1 Lloyd's Rep 374 (holding that the English action for breach of duty 'does not relate to the winding-up of insolvent companies or other legal persons, judicial arrangements, compositions or analogous proceedings; it is purely collateral that the plaintiff is in a state of suspension of payments', ibid, 400).

91 See, e.g., H Altmeppen and A Ego, 'Europäische Niederlassungsfreiheit', in W Goette and M Habersack (eds), Münchener Kommentar zum Aktiengesetz (Munich, CH Beck, 3rd edn, 2012), 389-405 (reviewing the different opinions and advocating a classification of the duty to file and civil and criminal liability for violation of the duty as company law).

${ }^{22}$ Insolvency Regulation, art 4.

${ }^{93}$ Ibid.

${ }^{94} \mathrm{Ibid}$, art 4(2).

${ }^{95}$ Spanish Insolvency Act, art 172bis, as amended by Act 38/2011 of October 10, 2011. 
insolvency proceedings pursuant to the above principles. ${ }^{96}$ Thus, as before, the directors' general corporate law duties are not governed by the lex concursus. ${ }^{97}$ It is less clear whether this also holds if the law provides for a discernible shift of the duties in the vicinity of insolvency, in the sense that the directors have to act primarily in the interest of the creditors, rather than the shareholders. ${ }^{98}$ The guiding principles established by the Court of Justice are ambiguous. In Gourdain, the Court held that the liability action at issue (liability for part of the debts of an insolvent company pursuant to French law) was to be classified as insolvency law because it 'derogate[d] from the general rules of the law of liability', ${ }^{99}$ i.e. here the rules on civil liability of directors. This is not true for creditor-regarding duties in the vicinity of insolvency, which derive from the general law on directors' duties. While they may predominantly (but not exclusively ${ }^{100}$ ) be brought by the liquidator and are owed to the body of creditors, not to individual creditors, they operate within the framework of the directors' general duties, and liability follows largely the same conditions. Not surprisingly, the literature has expressed some uncertainty how to classify them. ${ }^{101}$

The proposal for a Regulation amending the Insolvency Regulation does not clarify this issue. It explicitly extends the scope of the Regulation to include actions closely linked with insolvency proceedings, thus codifying the case law of the Court of Justice, ${ }^{102}$ but does not elaborate on the requirements of 'closely linked with', and 'directly deriving from', the insolvency. ${ }^{103}$ The proposal also stipulates that actions based on general civil and commercial law that are related to such closely linked actions and are directed against the same defendant may be brought by the liquidator in the courts of the Member States where the defendant is domiciled. ${ }^{104}$ Thus, upon the election of the liquidator, liability claims under insolvency law and company law or general tort law are concentrated in the same court. The law governing these actions, however, is determined independently in accordance with the connecting factors of insolvency, company, or tort law, as

${ }^{96}$ L Collins et al, Dicey, Morris \& Collins on the Conflict of Laws (London, Sweet \& Maxwell, 15th edn, 2012), 30-208.

${ }^{97}$ Instead, the lex societatis applies. For the UK, see, e.g., Konamaneni v Rolls Royce Industrial Power (India) Ltd [2002] 1 W.L.R. 1269.

${ }^{98}$ For example, this is the case in the UK, see West Mercia Safetywear Ltd v Dodd [1988] BCLC 250. Note that Grupo Torras, supra n 90, did not deal with creditor-regarding duties in the vicinity of insolvency, but general directors' duties.

${ }_{99}$ Gourdain, supra n 82, para 5. See also Case C-111/08 SCT Industri AB i likvidation v Alpenblume AB [2009] ECR I-5655 (holding that a transfer of shares by the liquidator came within the bankruptcy exception of the Judgments Regulation because it was based on a power of the liquidator derived 'specifically from provisions of national law governing [insolvency] proceedings', which "derogate[d] from the general rules of private law and, in particular, from property law", ibid, paras 27-28).

100 See Colin Gwyer and Associates Ltd v London Wharf [Limehouse] Ltd [2003] 2 BCLC 153.

101 See the tentative comments by Moss et al, supra $\mathrm{n} 71,8.167$.

102 In particular Deko Marty, supra n 82.

103 Supra, n 72 , art $3 \mathrm{a}(1)$, as amended.

${ }_{104} \mathrm{Ibid}$, art 3a(2), as amended. Actions are 'deemed to be related where they are so closely connected that it is expedient to hear and determine them together to avoid the risk of irreconcilable judgments resulting from separate proceedings'. Art $3 \mathrm{a}(3)$, as amended. 
applicable. Therefore, while the concentration of the actions in one forum may generate efficiency gains, ${ }^{105}$ the potential for conflicting substantive rules or regulatory gaps because of the different calibration of the Member States' substantive rules is not addressed. ${ }^{106}$

\section{Company law}

In international company law, the place of incorporation is now the predominant connecting factor in the EU. However, controversies remain as regards, first, the authority of host Member States to supplement the law of the incorporation state by applying some of their rules to companies with most or some of their operations within their territory, and second, the reach of the lex societatis. Both points are connected because the application of host State provisions in an area that falls within the scope of the lex societatis, as determined according to the incorporation theory, would require an argument based on public order (ordre public) or the mandatory, overriding nature of the provision to be applied.107 On the other hand, the application of a provision that falls outside the scope of the lex societatis would not require such an argument. To put it differently, if the host Member State decides to apply individual rules or sets of rules to companies validly incorporated in another Member State, such application is permissible if the rule is either, for purposes of private international law, to be classified as falling outside of company law (and, hence, governed by a different connecting factor that refers to the law of the host State), or it is an overriding norm that applies regardless of the application of the home State's company law. ${ }^{108}$ In both cases, the host State's rule must, of course, be in compliance with the freedom of establishment. It may be argued that the rule is more likely to constitute a restriction of the right of establishment in the latter case, because the presumption under EU law is that the company is governed comprehensively by the home State's company law, and that the burden for justification is higher, because the Court has been reluctant in its existing right of establishment jurisprudence to

\footnotetext{
105 Proposal for a Regulation, supra, n 72, recital 13b, as amended.

106 This problem is discussed in more detail infra Section D.

107 Such provisions are called overriding statutes, lois d'application immediate, or Eingriffsnormen. Overriding statutes have been described as 'crystallised rules of public policy' and are, thus, related to the notion of ordre public, Dicey, Morris \& Collins, supra n 96, 1-061. They apply irrespective of the applicable law pursuant to the normal conflict rules, ibid, 1-053. If the lex societatis is determined according to the real seat theory, assuming that it is still applicable in light of the right of establishment jurisprudence of the Court of Justice, the host State would, of course, not need to resort to the ordre public or overriding statute argument. The only problem would be the demarcation of the part of the host State's company legislation that is in conformity with arts 49, 54 TFEU and the part that could not be applied to a company validly established in another Member State. This, in turn, depends on the allocation of regulatory authority between the home and host States that we discussed above. Since it is now widely (but not universally, see, e.g., Altmeppen and Ego, supra n 91, para 285) accepted that the incorporation theory prevails and aspires to offer a comprehensive and exhaustive regulatory regime in the sense of home State control (see supra text to $\mathrm{n} 18$ ), we do not explore this possibility here.

${ }^{108}$ For an example of such an overriding norm in the field of company law see Altmeppen and Ego, supra n 91, para 351 (arguing that certain aspects of German capital requirements law should apply irrespective of the lex societatis).
} 
accept that a restriction is proportionate where the use of an appropriate company name puts the creditors on notice that the company is governed by a foreign company law system. ${ }^{109}$ These considerations do not apply in the same way to rules stemming from other areas of the host State's law. On the other hand, the Court of Justice does not distinguish explicitly between both cases and questions of restriction and justification have to be assessed pursuant to the same basic principles of EU law.

The principles determining the reach of the lex societatis are fairly well established in incorporation theory states, but less so in states that have only recently, under the impression of the case law of the Court of Justice, begun to move towards relying on the registered seat as the main connecting factor. English law provides that the law of the place of incorporation governs the formation and dissolution of the company and the internal management structure, including the composition and rights of the company's organs, the duties of the directors, the potential liability of the members for the debts of the company, the rules on distributions, and the right of the members to bring a derivative action. ${ }^{110}$ The demarcation is similar in other incorporation theory states. ${ }^{111}$ The list shows that, while the focus of the lex societatis is on internal management matters, it is not possible to draw a clear dividing line between internal and external affairs of the company. ${ }^{112}$ The position of the company's creditors is a function of several concepts that are governed by the lex societatis, as traditionally understood, notably the capital requirements of the incorporation law, restrictions on distributions to the shareholders, and strategies to pierce the corporate veil, as well as legal mechanisms that fall within the domain of contract law in the case of voluntary creditors, tort law in the case of involuntary creditors, and insolvency law, as discussed in the preceding section.

The above principles and the case law of the Court of Justice on the interpretation of the scope of the Insolvency Regulation and the Judgments Regulation ${ }^{113}$ lead to ambivalent results when applied to the duties in the vicinity of insolvency. It is reasonable to argue that the duty to file for the opening of insolvency proceedings and liability for failure to file, as well as the liability for wrongful or fraudulent trading, should be classified as insolvency law. The duty is triggered by the company's insolvency (however defined) and is closely connected to the opening of the proceedings, which is explicitly covered by the Insolvency

\footnotetext{
109 See, for example, Centros, supra n 10, para 36.

110 See Dicey, Morris, and Collins, supra n 96, Rules 174 and 175(2), with references. See also the exception in Regulation (EC) No 593/2008 of 17 June 2008 on the law applicable to contractual obligations (Rome I) [2008] OJ L177/6, art 1(2)(f).

111 See S Rammeloo, Corporations in Private International Law (Oxford University Press, 2001), 115-122 for the Netherlands and 159-163 for Switzerland.

112 The distinction between internal and external matters has been a concern of private international company law for a long time. For a summary of the different approaches see Rammeloo, supra n 111, 2023.

113 Insolvency Regulation, arts 3(1), 4; Judgments Regulation, art 1(2)(b). See supra, text to notes 82-90.
} 
Regulation. ${ }^{114}$ The liquidator is often involved in the action; for example, the liability for wrongful and fraudulent trading is imposed on the application by the liquidator. ${ }^{115}$ On the other hand, the duty to file operates before the insolvency proceedings have been opened. The Insolvency Regulation is concerned with the conditions for the opening, i.e. the procedural aspects of the opening, for example who may present the petition, ${ }^{116}$ but not the duty-based position of the director leading up to the opening of the proceedings. While the liability action against the director is enforced by the liquidator in some jurisdictions, this may not be the case in others. For example, German law distinguishes between two types of action by the company's creditors arising out of the failure to file for the opening of insolvency proceedings without culpable delay. The two types derive from the same legal basis, ${ }^{117}$ but they differ in their content. The creditors whose claims existed at the time when the duty to file arose are limited to recovering the loss suffered because of the delay in filing, i.e. the difference between the recovery rate that they could have obtained in the case of timely filing and the actual rate (socalled 'rate reduction loss' or Quotenschaden). Post-duty creditors, on the other hand, can claim the loss suffered because they relied on the company not trading in a state of insolvency when they entered into the transaction with the company (reliance interest or Vertrauensschaden). ${ }^{118}$ Importantly, the courts have held that the rate reduction loss can only be recovered by the liquidator in the course of the insolvency proceedings, whereas post-duty creditors have standing to sue individually. ${ }^{119}$ If insolvency proceedings are not opened because of the insufficiency of assets, all creditors, including the pre-duty creditors, have standing to bring an action individually. 120 These differences in the formulation and operation of the duties in the Member States create considerable difficulties for an autonomous interpretation of the scope of the Insolvency Regulation, and hence the determination of the dividing line between the lex societatis and the lex concursus at the European level.

The problems in classifying the directors' creditor-regarding duties have been discussed above. ${ }^{121}$ Finally, duties relating to the capital structure of the company, for example the duty to convene the general meeting and recapitalise the company or liability for undercapitalisation (and other variants of the concept of piercing

\footnotetext{
114 Insolvency Regulation, art 4(2).

115 UK Insolvency Act 1986, ss 213(2), 214(1).

116 Virgos-Schmit Report, supra n 83, para 90.

117 Insolvency Code, s 15a, in conjunction with Civil Code, s 823(2). Leading case is BGH [Federal Court of Justice], judgment of 6 June 1994, II ZR 292/91, BGHZ 126, 181 (see ibid, 190-191, confirming, in reliance on BGH, judgment of 16 December 1958, VI ZR 245/57, BGHZ 29, 100, that all creditors fall within the protective scope of Civil Code, s 823(2), not only those who were already creditors when the director should have filed for the opening of insolvency proceedings).

118 BGHZ 126, 181, 192-201. For a review of the historical development and operation of the German rules see M Schillig, 'The Transition of Corporate Governance to Bankruptcy Governance Convergence of German and US law?' (2010) 7 ECFR 116, 126-137.

119 BGHZ 126, 181, 201.

${ }^{120}$ Schillig, supra n 118, 135.

${ }^{121}$ See supra text to notes 98-101.
} 
the veil ${ }^{122}$ ), do not satisfy the conditions of the Court of Justice for an insolvency classification established in Gourdain and Deko Marty. ${ }^{123}$ However, functionally, they are comparable with the legal strategies used to protect creditors in the vicinity of insolvency or in insolvency that have been held by courts to fall within the scope of the Insolvency Regulation. ${ }^{124}$ Not surprisingly, in light of these ambiguities, the legal situation in the Member States regarding the scope of the lex societatis and the delimitation of private international company law and insolvency law is characterised by great uncertainty. With respect to almost all of the aforementioned legal strategies, views can be found in the same or in different Member States that suggest a classification according to company law, insolvency law, or yet another field of law. ${ }^{125}$

\section{Non-contractual obligations}

As in insolvency law, the conflict rules determining the law applicable to noncontractual obligations have been unified in the EU by the Rome II Regulation. ${ }^{126}$ According to the views of courts and commentators in some Member States, two types of non-contractual obligations may be relevant in the vicinity of insolvency: tort law and culpa in contrahendo. ${ }^{127}$ The connecting factor in tort law is the place where the damage occurs, thus leading to the application of the lex damni, ${ }^{128}$ unless the party alleged to be liable and the damaged party have their habitual residence in the same country, in which case that country's law applies irrespective of the place where the damage occurs, ${ }^{129}$ or the tort is 'manifestly more closely connected' with another country. ${ }^{130}$ The Regulation defines culpa in contrabendo as 'a non-contractual obligation arising out of dealings prior to the conclusion of a contract'. Such obligations are governed by the law that applies, or would have applied, to the contract. ${ }^{131}$ Alternatively, if that law cannot be determined, the three connecting factors of the private international law rules governing torts apply. ${ }^{132}$

\footnotetext{
122 See, for example, BGH [German Federal Court of Justice] judgment of 28 April 2008, Az. II ZR 264/06, BGHZ 176, 204 ('Gamma') (discussing the requirements for liability of the shareholders based on Civil Code, s 826, for causing the company's insolvency (existenzvernichtender Eingriff)).

123 Supra text to notes $82-84,99$.

124 Supra notes 85-89.

125 For example, see the opinions reviewed in Altmeppen and Ego, supra n 91, paras 391-405, submitting that the duty to file for the opening of insolvency proceedings and liability for failure to file should be classified: (1) both as insolvency law; (2) both as company law; (3) duty to file as company law and liability as tort law; (4) duty to file as insolvency law and liability as tort law; or (5) both as company law, but with the real seat as the relevant connecting factor.

126 Regulation (EC) No 864/2007 of 11 July 2007 on the law applicable to non-contractual obligations (Rome II) [2007] OJ L199/40.

127 Rome II Regulation, art 12.

128 Rome II Regulation, art 4(1).

129 Ibid, art 4(2).

130 Ibid, art 4(3).

131 Ibid, art 12(1).

132 Ibid, art 12(2).
} 
The dividing line between the Rome II Regulation and company and insolvency law is not well established. The Regulation excludes from its scope of application 'non-contractual obligations arising out of the law of companies [...] such as the $[\ldots]$ internal organisation and winding-up of companies and $[\ldots]$ the personal liability of officers and members as such for the obligations of the company'. ${ }^{133}$ While, for example, the liability of directors for a breach of duty is, therefore, outside the scope of Rome II, ${ }^{134}$ this is less clear where the directors' or members' responsibility is not directly related to the company's internal governance structure and does not depend on their position as director or member, for example where they are held liable according to principles of piercing the corporate veil or because they failed to file for the opening of insolvency proceedings. ${ }^{135}$ As regards the latter case, it has been argued that the liability of directors should be classified as tort law ${ }^{136}$ or, with respect to the creditors that enter into transactions with the company after the duty arose, as culpa in contrahendo.137 Further, where international tort law applies, some commentators submit that the rule of the closest connection would lead to an application of the law at the COMI. ${ }^{138}$ However, this approach disregards the subsidiary nature of the closest connection as relevant choice of law rule. In addition, given how the Insolvency Regulation defines COMI, and leading courts in the EU interpret the term, ${ }^{139}$ it is not clear why this should necessarily be the case. For example, where the head office functions are performed in one state but most of the creditors and assets are located in another, it is reasonable to assume that the closest connection is with the latter state, even though COMI will most likely be in the former, in particular if the registered seat is also located there. ${ }^{140}$ Therefore, different laws may apply, depending on the conflict of laws approach of the lex fori, and the duties in the vicinity of insolvency may be governed by more than one legal regime.

In addition to such problems of interpreting the conflict rules, the laws of many Member States contain broadly phrased, open-ended tort law provisions ${ }^{141}$

\footnotetext{
$133 \mathrm{Ibid}$, art $1(2)(\mathrm{d})$.

134 See, for example, GP Calliess, Rome Regulations: Commentary on the European Rules on the Conflict of Laws (Wolters Kluwer, 2011), Article 1 Rome II, para 51.

$135 \mathrm{Ibid}$, para 52 (arguing that piercing the corporate veil should be classified as 'a general problem of (tort) law' and should, therefore, be covered by Rome II).

136 OGH [Austrian Supreme Court of Justice], decision of 31 August 2006, 6 Ob 163/06y.

$137 \mathrm{H}$ Altmeppen and J Wilhelm, Quotenschaden, Individualschaden und Klagebefugnis bei der Verschleppung des Insolvenzverfahrens über das Vermögen der $\mathrm{GmbH}^{\circ}$ (1999) Neue Juristische Wochenschrift 673.

${ }^{138}$ For a discussion and references see G Eckert, Internationales Gesellschaftsrecht (Wien, Manz, 2010), 369. 139 See supra notes $72-73$.

140 The main reason why commentators argue that the case is 'manifestly more closely connected' with the state where the COMI is located seems to be the concern that the director may otherwise be exposed to liability pursuant to the lex loci delicti commissi before it is possible to file for the opening of insolvency proceedings in the second state. For solutions to this problem see Eckert, supra n 138, 369.

141 The paradigm are arts 1382, 1383 of the French Civil Code. Art 1382 provides that ' $[a]$ ny act whatever of man, which causes damage to another, obliges the one by whose fault it occurred, to compensate it'. This general tort law provision can be found in many countries of French legal origin, see, for example, Belgian Civil Code, arts 1382, 1383; Luxembourg Civil Code, arts 1382, 1383. Countries of other legal
} 
that are utilised in the vicinity of insolvency (or before) to hold directors liable for acts that harm the creditors. ${ }^{142}$ If these liability provisions operate independently of insolvency situations, it may be natural to classify them as tort law for purposes of private international law. ${ }^{143}$ It is also suggested by some commentators that the tort law classification holds for vicinity of insolvency situations. ${ }^{144}$ In these cases, the applicable law is again composed of parts of several national legal systems, with the ensuing risk of inconsistent or incomplete regulation.

\section{Other legal areas}

The legal strategies outlined above, focussing on duties and ensuing civil liability, are in all EU Member States supplemented by administrative and criminal sanctions. In some Member States, these sanctions constitute the main deterrent to misconduct by directors in the vicinity of insolvency (or, indeed, during any stage of a company's life). Two mechanisms are of particular importance as substitutes for other strategies that operate potentially sub-optimally: the disqualification of directors and criminal liability in the context of insolvency, typically attaching to the misappropriation of corporate assets, fraudulent misstatements in the balance sheet or the profit and loss accounts, unlawful preference of creditors, or the failure to file for the opening of insolvency proceedings. Often, these mechanisms are governed by separate conflict rules based on different considerations than those underlying private international company law or insolvency law. Private international law seeks to identify the legal system with the closest connection, ${ }^{145}$ because it is assumed that this is the most appropriate law to govern the case and that applying it conforms to the legitimate expectations of the parties. ${ }^{146}$ Administrative or criminal law, on the other hand, seeks to safeguard public interests. It is, therefore, generally restricted in its

origin that do not follow the French approach also often employ tort law amenable to flexible interpretation and application to different contexts, for example Dutch Civil Code, s 6:162(1) ('A person who commits a tortious act (unlawful act) against another person that can be attributed to him, must repair the damage that this other person has suffered as a result thereof'); German Civil Code, s 823(2) (the duty to pay damages applies to 'a person who commits a breach of a statute that is intended to protect another person')

${ }^{142}$ For example, liability pursuant to German Civil Code, s 823(2), was held to be triggered where the director violated various duties of a criminal and insolvency law nature, including, the failure to file for the opening of insolvency proceedings, see BGH [Federal Court of Justice], judgment of 06 June 1994, II ZR 292/91, BGHZ 126, 181.

143 See, for example, Hof Leeuwarden, 11 June 2008, JOR 2009, 20; NWA Tollenaar, 'Bestuurdersaansprakelijkheid en IPR (II)', TFZI 2009/7, 206, for Dutch tort law.

${ }^{144}$ For references see Altmeppen and Ego, supra n 91, paras 392, 397.

145 So-called principe de proximité, see P Lagarde, 'Le principe de proximité dans le droit international privé contemporain' (1986) 196 Recueil des Cours 9.

146 M Rheinstein, 'The Place of Wrong: A Study in the Method of Case Law' (1944-1945) 19 Tulsa Law Review 4, 20. 
applicability to the territory of the state, but is not concerned with the closest connection to the facts. ${ }^{147}$

The UK rules on directors' disqualification ${ }^{148}$ are a good example. They apply to the director of 'any company which may be wound up under [...] the Insolvency Act'. ${ }^{149}$ Because of the wide interpretation of the grounds for winding up a foreign company by the English courts, which essentially only presuppose a 'sufficient connection' with the UK, ${ }^{150}$ the connecting factor is considerably broader than that of private international company law or the Insolvency Regulation. The tendency to apply disqualification rules more expansively than company law proper can also be seen in other countries. The functional substitute of the UK directors' disqualification regime in German law is the requirement that company directors shall not have been subject to an order prohibiting the person from carrying out a profession that falls within the company's objects or have been convicted of specified criminal offences, in particular insolvency offences. ${ }^{151}$ These provisions apply to the directors of private and public limited companies formed pursuant to the German legislation and, consequently, with their registered seat in Germany. In addition, courts have applied them to directors of foreign limited companies with all or almost all of their operations in Germany. In the leading case, the German Federal Court of Justice upheld the refusal to register the branch of an English private limited company whose sole director was subject to a professional ban in Germany, arguing that, 'as regards the branch, the appointment of the director was not valid in light of the mandatory grounds for disqualification laid down in s 6(2) of the Limited Liability Companies Act'. ${ }^{152}$ Thus, the court did not question the validity of the appointment of the director from the perspective of English company law, but applied the German prohibition to the company as far as its operations in Germany were concerned. ${ }^{153}$ The court explicitly referred

147 See e.g. PJ McConnaughay, 'Reviving the Public Law Taboo in International Conflict of Laws' 35 (1999) Stanford Journal of International Law 255.

148 Company Directors Disqualification Act 1986, c. 46.

$149 \mathrm{Ibid}, \mathrm{s} 22(2)$.

150 The case law is summarised by Dicey, Morris, and Collins, supra n 96, Rule 176(2), and Fletcher, supra n 79, 3.23-3.45. Fletcher explains that a 'sufficient connection' with the UK, which is the main requirement for a just and equitable winding-up pursuant to Insolvency Act 1986, s 221(5)(c), may result from the location of assets within the jurisdiction, the reasonable possibility that a winding-up order will benefit those who apply for the order, and the court's jurisdiction over persons interested in the distribution of the company's assets, ibid, 3.44-3.45. If the directors' disqualification falls outside the scope of the Insolvency Regulation, as has been argued in the literature (Moss et al, supra n 71, 8.168), these common law criteria apply.

${ }^{151}$ Limited Liability Companies Act, s 6(2), sentence 2, no. 2, 3; Stock Corporation Act, s 76(2), sentence 2, no. 2,3 .

152 BGH, decision of 7 May 2007, II ZB 7/06, NZG 2007, 592, para 12 (emphasis added).

153 The court also discussed the compatibility of the application of German law with the right of establishment and the 11 th Company Law Directive (Directive 89/666/EEC). Relying on Inspire Art and Centros, the court argued that the appellant's conduct constituted abuse and, consequently, the appellant was not entitled to invoke the Treaty freedoms. In any case, the restriction was justified in light of overriding reasons in the public interest, namely the protection of creditors, minority shareholders, and consumers, as well as the integrity of commerce and trade, supra $\mathrm{n} 152$, paras 17-24. The holding was codified in 2008 in the Commercial Code, s 13e(3), sentence 2, as amended by Gesetz zur Modernisierung des GmbH-Rechts und zur Bekämpfung von Missbräuchen (MoMiG) [Law for the 
to the principle of territoriality and the public interests that the disqualification order sought to protect in order to justify the application of German law. ${ }^{154}$ Where such public interests are engaged, market actors are, accordingly, potentially subject to more than one regulatory regime. ${ }^{155}$

The territoriality principle also governs the international reach of the criminal laws of most Member States. Therefore, the general rule is that criminal liability, for example for the failure to file for the opening of proceedings without culpable delay, transactions in fraud of creditors, incorrect disclosures, and default in filing, or falsification of, the company's accounts and reports, attaches to criminal acts committed within the state's territory. ${ }^{156}$ Whether criminal liability does, in fact, arise, depends on whether the elements of the offence have been satisfied. If some of these elements are legally qualified terms, which will often be the case in the context of corporate crime, the question is how these incidental questions should be treated for purposes of private international law. The classification of incidental questions that are contained in provisions of public law does not follow universally applicable and accepted rules, but may be judged according to the conflict rule of the lex fori applicable to the incidental question or, depending on the function of the public law, the forum's substantive law. ${ }^{157}$ For duties in the vicinity of insolvency or in insolvency, it is convincing to apply the forum's private international law, since the respective elements of corporate crimes are technical terms that should be construed as expressed in the conflict rules. In any case, the conflict rules may lead to the application of multiple legal regimes, which may give rise to friction. For example, where a director who is resident in Member State A gives an unlawful preference to creditors and the company's COMI is located in Member State B, the case is governed by the criminal law of Member State A and the insolvency law of Member State B.

\section{INCOMPLETE SYSTEMS}

As discussed in the preceding section, national legal systems often do not confine their efforts of regulating social conflicts arising in relation to companies in the

Modernisation of the German Limited Liability Company Law and the Prevention of Misuse], Law of 23 October 2008, BGBl. I, 2026, art 3(3)(b). It is submitted in the literature that the rules do not only apply to the registration of a branch in Germany, but generally when the effects of the legal acts of a company director in Germany are at issue, with the consequence that the director would lack actual authority to represent the company, Altmeppen and Ego, supra n 91, para 477.

${ }^{154} \mathrm{Ibid}$, para 23.

155 Other provisions that were held to apply irrespective of the applicable company law are the rules on corporate names (eg, German Commercial Code, ss 18, 30), see OLG München [Higher Regional Court Munich], decision of 1 July 2010, 31 Wx 88/10, NZG 2011, 157; Kammergericht [Higher Regional Court Berlin], decision of 11 September 2007, 1 W 81/07, FGPrax 2008, 35.

156 Altmeppen and Ego, supra n 91, 617.

${ }^{157} \mathrm{~J}$ Samtleben, ,Zur kollisionsrechtlichen "Vorfrage“ im öffentlichen Recht" (1988) 52 RabelsZ 466. 
vicinity of insolvency to one specific area of law, ${ }^{158}$ and they have not, at least until recently, paid close attention to the 'classification problem' - i.e. the problem of different connecting factors for different areas of law - in designing their regulatory responses. Conflict rules, including the harmonised parts of private international law, thus do not always reflect the functionality of the law, and it is often essentially random on which side of the different conflict-of-laws boundaries a particular regulatory strategy falls.

It is worth noting that this problem may well affect different Member States in systematically different ways. Jurisdictions that traditionally applied the real seat doctrine may be expected to have paid less attention to the classification problem than incorporation doctrine countries. Their traditional conflicts rules ensured that most companies with substantial operations within their territory had to use a national corporate form. Thus, when the legislator faced social or economic conflicts, or where courts developed legal doctrine to respond to emerging problems related to the activity of corporations, company law was as good an area of law as any other for addressing the issue. For most of the past century, companies operating in real seat states would almost necessarily be subject to the national insolvency law, company law, tort law, and criminal law of that jurisdiction. In jurisdictions traditionally following the incorporation doctrine, on the other hand, the potential dissection of the national legal framework must have been much more present in the minds of both legislators and judges. As these jurisdictions traditionally permitted companies formed under the law of another country to operate within the confines of their national economies, even where such companies primarily operated in and thus affected the country of incorporation, these legal systems can be expected to have been more careful in "localising" their regulatory requirements within their own legal systems. Indeed, as can be seen from the discussion above, jurisdictions with a long-standing incorporation doctrine tradition seem somewhat better prepared for the type of corporate mobility, and thus the ensuing risk of regulatory arbitrage, made possible by the jurisprudence of the Court of Justice. English law, for instance, opened the door for foreign companies centuries ago, ${ }^{159}$ while German law was forced into this approach by the Court a mere decade ago, ${ }^{160}$ and still only accepts it in relation to EU companies. Thus, it should come as no surprise that German law considered a company law-based approach to director disqualification as entirely appropriate, ${ }^{161}$ although it now seems to adapt to the new situation, ${ }^{162}$ while English law casts its net much wider. ${ }^{163}$ Similarly, the re-characterisation of

\footnotetext{
158 See also K Schmidt, 'Grounds for Insolvency and Liability for Delays in Filing for Insolvency Proceedings' in: M Lutter (ed), Legal Capital in Europe (Berlin, De Gruyter 2006) 144, 147, highlighting the interplay between rules from different areas.

159 See Henriques v Dutch West India Company (1728) Ld Raym 1532, 92 ER 494.

${ }_{160}$ Case C-208/00 Überseering BV v Nordic Construction Company Baumanagement GmbH (NCC) [2002] ECR I-9919.

161 See section 76(3) of the German Stock Corporations Act (AktG); see supra text to n 151.

162 See supra text to 152.

163 See supra text to 148.
} 
shareholder loans had originally been created as a company law rule in Germany, although the problem the rule tries to address is clearly not confined to domestic corporations, and the rule has now been 'moved' to insolvency law. ${ }^{164}$ Similar examples exist in relation to other regulatory strategies.

If the above analysis is correct, i.e. if Member States, particularly Member States traditionally following the real seat doctrine, have indeed at least traditionally tended to address a variety of problems related to the activities of companies in distinct areas of law, this may pose a challenge to the presumption of equivalence discussed in section B above. By making use of the freedom of establishment, however, companies become subject to less coherent, and often overlapping and/or misaligned regulatory regimes from different Member States, as conflict of laws rules dissect coherent sets of national legal rules. While it seems reasonable to assume that Member State laws are in fact largely equivalent in so far as they all attempt to address the most important problems arising from the conduct of business in the corporate form - not least because they have strong incentives to do so - this no longer holds true where we are concerned with parts of national laws. The 'dissection problem' presents itself in two different guises, which are not equally susceptible to practicable solutions. We will address both in turn.

\section{Classification Problem}

The first problem may arise due to the different categorisation of regulatory strategies across Member States. For purposes of this point, we may hypothesize, somewhat unrealistically, that most social or economic disputes are addressed in relatively discrete, coherent 'parcels' of law. Under this assumption, a company by exercising the freedom of establishment and triggering different connecting factors would become subject to such parcels of law originating from different jurisdictions. The different categorisation of these parcels in the Member States' domestic laws would ultimately not be relevant as far as the cross-border movements of companies are concerned. It is well established that the determination of the applicable law in cases with connections to more than one jurisdiction develops along functional lines and not according to the categories of the domestic law. The relevant connecting factor is identified through classification ${ }^{165}$ of the problem at hand, i.e. the identification of the conflicts rule that governs the situation. While rules of private international law generally use

\footnotetext{
164 See text to $n 89$.

165 Also called 'characterization', see E Rabel, The Conflict of Laws, vol 1 (Ann Arbor, University of Michigan Law School, 2nd edn, 1958), 49-50.
} 
terminology stemming from the substantive (domestic) law, the interpretation of both types of law does not necessarily run parallel. ${ }^{166}$

This means that Member States have the possibility to classify the strategies addressing the misalignment of incentives in the vicinity of insolvency irrespective of their domestic categorisation in a way that functional substitutes of the lex for's legal strategies become applicable to the case at hand. At least where conflict rules are unified, it can be expected that this type of classification along functional lines will lead to a coherent regulatory regime for cross-border situations that avoids regulatory gaps, since the classification will ultimately be based on a European understanding of the relevant areas of law, guarded by the Court. Two problems would still persist, however. First, the different national approaches towards classification may create considerable legal uncertainty. While this would mainly be a temporary problem, it could still act as a powerful de facto restriction of crossborder mobility of companies until most open questions have been addressed by the Court. Second, one may argue that companies in this scenario are subject to a complete set of rules, but these rules would have been created by different legislators, and the solutions of the problems they address may well be different. This would however also hold true where all Member States apply the same private international law classification, and if one embraces the benefits of legislative competition and horizontal learning between Member States, this would certainly not be a prima facie undesirable result. Also, to the extent that the argument is based on the undesirability of different outcomes, it bears no weight: as described above, the choice between different regulatory solutions, even in a 'pure' form, ${ }^{167}$ will not be regarded by the Court as justifying national legislative intervention.

Currently, of course, the Member States are far away from a harmonised understanding of the conflict rules and their scope. As the discussion above has shown, ${ }^{168}$ Member States disagree both about the interpretation of the connecting factors relevant in the vicinity of insolvency, including those that stem from EU law and are, therefore, to be interpreted autonomously, and the reach of the lex societatis, lex concursus, and other applicable laws. ${ }^{169}$ They classify legal strategies from different jurisdictions that operate as functional substitutes differently, with the consequence that none of the substitutes may apply, or more than one cumulatively, depending on the distribution of the COMI, registered seat, and other connecting factors across Member States. For example, the liability for failure to file for the opening of insolvency proceedings and its functional equivalents (fraudulent and wrongful trading, action en responsabilité pour insufissance

\footnotetext{
166 This is the case even if the classification is governed by the lex fori, which is now the prevalent view (for a discussion of the different views see ibid, 52-66), because the conflicts rule must be sufficiently open-ended to capture not only domestic, but also foreign legal relationships.

167 See text to $n 16$.

168 Section C.2.

169 See also Schmidt, supra n 158, at 146.
} 
d'actiff) are classified in some countries as company law, ${ }^{170}$ in others as tort law, ${ }^{171}$ and yet in others as insolvency law. ${ }^{172}$ Assume that a company is incorporated in Member State A, which addresses the problem of a delay in the filing for the opening of insolvency proceedings under the rubric of wrongful trading, classified as insolvency law. Assume further that the company has its COMI in Member State B, which classifies liability for the failure to file as company law. If insolvency proceedings are opened in Member State B, the court will determine the applicable law according to the location of the registered seat. Conflict of law rules generally refer to the domestic (substantive) law as well as the conflict rules of the lex causae, here the law of A. ${ }^{173}$ The conflict rules of A are interpreted by the courts of $\mathrm{B}$ from the perspective of the lex causae. ${ }^{174}$ From that perspective, the question at hand is one to be solved by, and classified as, insolvency law. Consequently, A's conflict rules declare that the law of B as the law at the place of the COMI is applicable. The renvoi now only refers to B's internal law, not to rules of private international law. ${ }^{175}$ Depending on how B's courts will treat the issue, regulatory gaps may arise since the liability provision is not part of insolvency law from B's point of view. ${ }^{176}$

Now assume that the company's COMI is located in a Member State that classifies the liability for the failure to file as tort law. ${ }^{177}$ If most of the company's creditors are based elsewhere, say, in Member State C, then the place where the damage occurred within the meaning of the Rome II Regulation is $\mathrm{C}^{178}$ and, consequently, the law of this Member State is applicable. ${ }^{179}$ The reference is to the internal law of C. 180 Therefore, the courts of the Member State where COMI is located would need to analyse the director's potential liability according to legal instruments that are not designed to address the problem at hand.

Finally, assume that the company is incorporated in Germany and its COMI is located in England. The English court opens insolvency proceedings and the

\footnotetext{
${ }^{170}$ For example Germany, but the issue is controversially debated, see the references in Altmeppen and Ego, supra n 91, para 391.

171 Austria, see supra n 136

172 France and UK, see supra notes 87-88.

173 See, for example, Introductory Law to the German Civil Code, art 4(1), sentence 1.

174 Kropholler, supra n 182, \& 16 I.

175 This is a consequence both of the character of the Insolvency Regulation's referral, see Virgos-Schmit Report, supra n 83, para 87, and the private international law of many Member States, see, for example, Introductory Law to the German Civil Code, art 4(1), sentence 2.

176 Private international law doctrine offers certain possibilities for the courts of B to take recourse to other areas of internal law than those determined through A's classification (in our example insolvency law), see infra text to notes 182-183. However, clear rules on how this problem is to be treated do not exist.

177 See, e.g., supra notes 171, 136.

178 Rome II Regulation, art 4(1).

179 Unless the applicable tort law is determined according to the closest connection, which is interpreted as being automatically the COMI. This seems to be the opinion of the Austrian Supreme Court of Justice, see the reference supra $\mathrm{n}$ 136. However, this approach is difficult to reconcile with the text of the Rome II Regulation and the definition of COMI by the Insolvency Regulation, see supra text to notes 139-140.

180 Rome II Regulation, art 24.
} 
liquidator may apply to the court for an order declaring that the director is liable for wrongful or fraudulent trading. Classification problems do not exist; the English court simply applies its own insolvency law. However, according to the case law of the German Federal Court of Justice, creditors whose claims came into existence after the duty to file arose have standing to enforce their claims independently of the insolvency proceedings. ${ }^{181}$ Therefore, the director is potentially subject to two liability regimes cumulatively, even though the English law is structured to regulate the social conflict comprehensively.

These problems of regulatory gaps or overlaps of legal strategies can, of course, be solved by 'adapting' either the respective conflict rules or the applicable substantive law. For example, it is possible that the courts of Member State B in the first scenario will interpret the referral from A's law to the internal law of B expansively so as to encompass B's liability provisions, even if they would not do so for purposes of the initial classification. The notion of 'adaptation' has been developed in conflict of laws precisely to overcome the above friction that arises when two legal systems apply to one social problem. ${ }^{182}$ However, adaptation has the disadvantage of being highly fact-specific and not following generalizable rules. Rather, it is performed by the judge on an ad-hoc basis in the individual case to achieve an equitable outcome. Therefore, it adds to the legal uncertainty created by the differences in the interpretation of the conflict rules that still prevails in the EU. 183

\section{FunCtional Complements}

The problem of incomplete systems goes far beyond the difficulties stemming from diverging classification, however. Functional interdependencies between national legal rules may impede the functioning of a domestic rule that is used by private international law to reassemble a regulatory framework applied to a 'foreign' company.

Even where functional substitutes across jurisdictions can correctly be identified, and consistent classification ensures replacement of inapplicable legal instruments with such substitutes, this does not ensure coherence and compatibility within the reassembled framework. If and to the extent that applicable rules rely on functional complements from their own national legal system that do not exist in the host state (and that are situated outside of the transplanted parcel of law), problems will still arise.

\footnotetext{
181 Supran 118.

182 J Kropholler, Internationales Privatrecht (Tübingen, Mohr Siebeck, Gth edn, 2006), \34; J Schröder, Die Anpassung von Kollisions- und Sachnormen (Berlin, W. de Gruyter, 1961).

183 See PH Neuhaus, 'Legal Certainty versus Equity in the Conflict of Laws' (1963) 28 Law and Contemporary Problems. 795, 801.
} 
A similar friction is well-known and much-discussed in the context of 'legal transplants'. ${ }^{184}$ In the context of migrating companies it is brought about by the dissection of legal systems through conflicts rules, rather than by national legislators seeking inspiration abroad. The extent to which this poses a problem, of course, depends on the intensity of the cross-doctrinal interdependencies. In some cases the problem may well be manageable. After all, national courts have been dealing with similar problems in cross-border situations for centuries, as interdependencies between different foreign rules may play a role whenever a legal concept enters another jurisdiction. In other cases, however, a rule may rely on surrounding fields of law or on national institutions to an extent that it loses its meaning and function when having to operate outside its usual environment. In some cases, this problem has partly been addressed through harmonisation, e.g. where accounting rules, company law, and insolvency law interact. ${ }^{185}$ In other circumstances, problems still persist. For example, the dissection mentioned above will often result in the separation of a 'duty to file' from the 'triggering event', i.e. the definition of the point in time after which a company is regarded as insolvent under the applicable law. ${ }^{186}$ It seems obvious that divergences in the grounds for opening an insolvency proceeding (which are to be determined based on the COMI-law) change the operation of a filing duty (where the prevailing view is that it forms part of company law).

Moreover, solutions to economic and social problems - unsurprisingly - have developed across different areas of law and discrete functional substitutes to these regulatory solutions will often simply not exist. In order to illustrate this point, it may be useful to distinguish between three distinct stages in a company's life: first, insolvency or a time near insolvency when it should be clear that the company will not be able to avoid going into insolvent liquidation; second, a period of financial distress, during which it is, however, still reasonable to assume that the company will avoid becoming insolvent; and third, any time before the company experiences financial distress. While some legal strategies operate during all three stages, many can be associated with, or are designed to apply to, one of them in particular. Avoidance actions, the duty to file for the opening of insolvency proceedings, liability for the failure to file, for causing or aggravating the company's insolvency (action en responsabilité pour insufissance d'actif or responsabilidad concursal), or for wrongful or fraudulent trading, all require that the company is

\footnotetext{
184 See A Watson, Legal Transplants: An Approach to Comparative Law (Athens, University of Georgia Press, 2nd edn, 1993); see also H Spamann, 'Contemporary Legal Transplants: Legal Families and the Diffusion of (Corporate) Law' (2009) Brigham Young University Law Review 1813.

185 See the Fourth (Council Directive 78/660/EEC of 25 July 1978 on the annual accounts of certain types of companies, OJ L 222/11), Seventh (Council Directive 83/349/EEC of 13 June 1983 on consolidated accounts, OJ L 193/1), and Eighth Company Law Directives (now Directive 2006/43/EC of 17 May 2006 on statutory audits of annual accounts and consolidated accounts, OJ L 157/87). Important differences do still exist, however, especially outside of the scope of application of the IFRS Regulation (Regulation (EC) No 1606/2002/EC of 19 July 2002 on the application of international accounting standards, OJ L 243/1).

186 See e.g. Eckert, supra n 138, 376, and the discussion in section C.2 above.
} 
insolvent, that there is no reasonable prospect of avoiding insolvency, or that the director caused or contributed to the insolvency. These duties are supplemented by administrative and criminal sanctions that also require the company's insolvency. In addition, a number of strategies relating to the company's capital structure operate during or in the vicinity of insolvency, for example the duty to recapitalise or liquidate or the reclassification of shareholder loans as equity. Before insolvency, but during times of financial distress, fiduciary duties may require the directors to pay particular regard to the interests of the creditors, and the aforementioned mechanisms designed to protect the company's capital are already of importance. Finally, before the company nears insolvency, the regular duties of directors intend to ensure that the company is managed prudently. In addition, stringent capital requirements may influence the likelihood that the company will experience financial distress at a later stage.

Functional interdependencies exist both between the legal strategies within each group and between different groups. In any given legal system, more than one strategy is employed to address any one of the three social problems: harming creditors when the company is insolvent by continuing to trade or giving unlawful preference; excessive risk-taking when the company experiences financial distress; and the prudent management of a going concern. The respective strategies are, therefore, functional complements. Some of these functional complements may be selected, and others de-selected, by virtue of diverging connecting factors. When this is the case, it is necessary to find a functional substitute in the lex causae that applies pursuant to the conflict rule. Such a substitute may be identified through classification based on the relevant social conflict, in which case the applicable law continues to function harmoniously. In many cases, however, a perfect substitute will not exist because legal systems are conceptualised differently and operate in a distinct institutional environment. Adaptation ${ }^{187}$ may not possible where the legal instruments that function as substitutes are too different or their efficacy depends on legal or institutional conditions that are not present, and cannot easily be replicated, in the other jurisdiction. We may encounter this problem with respect to strategies addressing the same social problem, i.e. falling within the same of the three groups outlined above, for example where one state relies primarily on civil sanctions and the other on criminal sanctions to prevent companies from trading in a state of insolvency. The problem is even more pronounced where legal systems exploit the interdependencies between the different groups and focus, for example, on fiduciary duties before insolvency, or alternatively, on remedies during the insolvency stage, to protect creditors.

Take, for example, a rule like the 'recapitalise or liquidate' requirement. ${ }^{188}$ The rule clearly addresses the problem of limited liability companies continuing their operations at a time of waning equity, 189 and thus tries to reign in on the same perverse incentives as the liability for a breach of the duty to file or wrongful

\footnotetext{
187 See supra text to $\mathrm{n} 182$.

188 See supra Table 1.

189 See e.g. Enriques, supra n 21, 28.
} 
trading prohibitions. It may well be the case that this regulatory solution is a response to weaknesses in other, more direct, strategies in the relevant jurisdiction. But it would be difficult to view a 'recapitalise or liquidate' requirement as belonging to any area other than company law, even when taking a functional approach to the classification process. Similarly, some company laws require directors to manage a company in the interest of shareholders and stakeholders. ${ }^{190}$ While also clearly a company law rule, such a provision will likewise have an impact on the acceptability of risk-taking by near-insolvent companies in the relevant jurisdiction, and its existence will have played a role in shaping other parts of the law. Another important example of interdependencies is the interaction between civil and criminal enforcement. In some jurisdictions, for example France, enforcement takes place largely through criminal litigation, on which shareholder may 'piggyback'. ${ }^{191}$ The French regulatory regime constraining managerial decision-making would not be complete if the criminal sanctions, and the institutional apparatus used to enforce them, were disregarded. This part of the regulatory architecture, of course, will not be 'imported' where the lex fori refers to French law as lex causae and the criminal act has been committed within the territory of the lex fori.

Finally, a problem that cannot be solved through functional classification, harmonious interpretation of the scope of the applicable law, or adaptation is the focus of jurisdictions on different, but interconnected social conflicts in their regulatory regimes. In some countries, for example Spain or Portugal, fiduciary duties of directors are generally considered to be under-enforced. This does not seem to be so much a function of the deficient formulation of the duties in the company laws of these jurisdictions, ${ }^{192}$ rather than the consequence of a traditional attitude of passivity or reluctance towards private enforcement. However, the courts in these legal systems have forceful tools at their disposal to hold directors of an insolvent company liable who violate their duties before or in the vicinity of insolvency, and in practice most enforcement indeed takes place once a company has become insolvent. Under Spanish law, and similarly under Portuguese law, the insolvency will be qualified as either 'accidental' or 'culpable'. ${ }^{193}$ The latter is the case if the insolvency has been caused or aggravated by intentional or grossly negligent acts of the director. ${ }^{194}$ Intent or gross negligence is presumed, among

\footnotetext{
190 See e.g. Austrian law, which explicitly provides for the management of a company to be conducted in the interest of the company, its shareholders, its creditors, and the public interest; see section 70 Austrian Stock Corporation Act.

191 M Gelter, 'Why Do Shareholder Derivative Suits Remain Rare in Continental Europe' (2011-2012) 37 Brooklyn Journal of International Law 843, 887-888.

192 Both countries contain a catalogue of well-defined, comprehensive duties of company directors and liability provisions, see Spanish Companies Act [Ley de Sociedades de Capital], ss 225-232; Portuguese Code of Commercial Companies [Código das Sociedades Comerciais], ss 64, 72, 78-79.

193 Spanish Insolvency Act [Ley Concursal], s 163. For Portugal see Insolvency and Business Recovery Code [Código da Insolvência e da Recuperação de Empresas], ss 185-189 (in particular liability pursuant to s 189(2)(e), as amended by Law 16/2012).

194 Spanish Insolvency Act, s 164.
} 
other reasons, if the director breached the duty to file for the opening of insolvency proceedings. ${ }^{195}$ In the case of a culpable insolvency, the court may, in its discretion, impose liability on all or some of the de jure or de factor directors who acted intentionally or grossly negligently for all or parts of the shortfall in the company's assets. ${ }^{196}$ A showing of causality between the breach of duty, for example the late filing, and the deficit in the company's assets is not required. In addition, the affected directors will be disqualified for at least two, and up to 15 years. ${ }^{197}$

These sanctions are stronger than the functional substitutes available in other legal systems, for example UK or German law. In the UK, the liability for wrongful trading is commonly interpreted as being compensatory in nature, i.e. directors are liable to make a contribution to the company's assets commensurate with the amount by which the assets have been depleted because of their conduct. ${ }^{198}$ The German liability provisions for failure to file without culpable delay generally restrict the amount recoverable to the rate reduction loss (Quotenschaden). They consequently also require a causal connection between the director's conduct and the loss suffered by the company. ${ }^{199}$ On the other hand, it can be said that these legal systems are somewhat more balanced because they also support considerable enforcement of directors' duties before insolvency, which arguably reduces the risk of the company experiencing financial distress and eventually having to file for insolvency. ${ }^{200}$ The general directors' duties before insolvency are classified as company law for purposes of private international law, whereas the liability provisions under Spanish or Portuguese insolvency law satisfy the definition of 'closely connected action' as developed by the Court of Justice and, therefore, fall within the scope of the lex concursus as determined by the Insolvency Regulation. If we now assume that a company's registered seat is located in a jurisdiction that focuses on the insolvency stage in order to address behaviour harmful to the creditors' interests, such as Spain or Portugal, and the COMI in a jurisdiction such as the UK or Germany, we observe what may be termed 'weak selection' of legal rules: the application of the two sets of rules that are the weaker components of the investor protection regimes of their respective jurisdictions, to the exclusion of the more effective instruments.

Thus, the interplay of corporate mobility and the diversity of connecting factors may jeopardise the underlying rationale of the 'choice of law'-model that

\footnotetext{
195 Ibid, s 165(1).

${ }^{196}$ Ibid, s 172 bis, as amended by Law 38/2011.

${ }^{197} \mathrm{Ibid}, \mathrm{s} 172(2)$.

198 In Re Produce Marketing [1989] 5 BCC 569, 597.

199 An exception exists for post-duty creditors, see supra, text to n 118.

200 The imbalance in Spanish law is attenuated by the existence of a provision imposing strict liability on directors for violating their duty to convene the general meeting and either recapitalise or liquidate the company where the company's losses exceed half of its equity capital, Spanish Companies Act, s 367. This provision has been litigated frequently and constitutes a significant liability risk for directors of Spanish companies. A comparable provision does not exist under Portuguese law, where the violation of the duty to recapitalise or liquidate only triggers criminal liability, which requires that the director acts intentionally, Code of Commercial Companies, s 523.
} 
the Court has effectively adopted. Furthermore, the gaps created by a lack of compatibility between different legal regimes may ultimately open the door to inefficient regulatory arbitrage of a 'cherry picking' kind. The problems are likely to be most acute where effective regulation relies on functional complements, i.e. where two or more legal fields necessarily interact and no clear or 'natural' boundary exists between them, as in the case of addressing the incentives of company directors and shareholders in the vicinity of insolvency.

\section{E. POSSIBLE SOLUTIONS}

What follows from our analysis? As has been argued above, the dissection of legal rules through what we regard as an incoherent approach to defining the regulatory spaces of Member States in the EU impedes corporate mobility and may at the same time create scope for inefficient types of regulatory arbitrage. The EU approach to corporate mobility is based on a presumption of equivalence which extends beyond the scattered areas of company law harmonisation. This presumption, however, loses its justification as Member State laws are dissected into discrete bundles of rules that are then stitched together by the applicable conflicts rules. Instead of choosing between competing - but coherent and complete - legal systems, incorporators can thus increasingly cherry-pick rules and exploit regulatory gaps that do not, in this form, exist in any one Member State, but are a mere consequence of dissection.

As outlined above, the problem is likely to be most prominent in areas such as creditor protection in the vicinity of insolvency, where almost all jurisdictions use regulatory tools from different areas of law - typically at least from both insolvency law and company law - to create a coherent legal framework. Although this is a suitable showcase, the problem is in no way limited to these situations, however, since functional interdependencies exist across virtually all areas corporate law seeks to address.

Is this a problem that can be solved without interfering with the Treaty freedoms? A strict real seat approach would avoid dissection in most cases, but as follows from Überseering, ${ }^{201}$ such an approach is incompatible with the Treaty freedoms. It would also prevent European companies from capitalising on the many benefits choice of law brings with it.

It is of course open to Member States to harmonise the relevant areas of law. The equivalence presumption may ultimately be based on Article 50(2)(g) TFEU, which provides a basis for the harmonisation of 'safeguards [...] for the protection of the interests of members and others'. If, as is argued here, problems exist that are intrinsically connected to the exercise of the Treaty freedoms, then this may seem

201 Supra n 11. 
a viable way. In reality, however, it is highly unlikely that Member States would ever agree to a level of harmonisation that would solve the problems identified above, given that such harmonisation would need to be far-reaching and cut across various different areas of law to address the problem of functional complements. If the experiences with the Takeover Directive, ${ }^{202}$ the European Company, ${ }^{203}$ or group law 204 are any guidance, it seems highly unlikely that harmonisation of (at the very least) company and insolvency law in all relevant aspects is a realistic option. ${ }^{205}$ In addition, apart from the theoretical problems, harmonising in the all-encompassing manner that would solve the problem is of questionable desirability. It would decrease the room that Member States have for experimentation, and most importantly it would preclude any tailoring of regulatory solutions to the particular needs of national economies, circumstances, and societal preferences.

Alternatively, one may rely on the development of reliable, functionally-based criteria to solve the classification problem. There is little doubt now that what constitutes insolvency law for the purposes of EU law is subject to a coherent, unitary interpretation. Member States cannot, therefore, simply decide for themselves whether to frame a particular rule as insolvency or company law and thus achieve a wider or narrower scope of application. ${ }^{206}$ Even if uncertainties exist now, they are likely to vanish over time. However, as pointed out above, ${ }^{207}$ this is only a solution where clear and discrete functional substitutes can be identified across different jurisdictions, and even then the problem of interdependence beyond the specific solutions would persist. Thus, even a coherent EU-wide approach to the classification problem is unlikely to solve the problem.

Alternatively, one could call for the Court to take into account the problems described here when assessing the compatibility of 'intrusive' national rules applied to foreign-incorporated companies. Member States would then be better placed to justify an application of national law to foreign-incorporated companies, irrespective of the rules' private international law classification, based on the factual inefficacy of otherwise applicable home state laws. In fact, nothing in the Court's jurisprudence prevents Member States from adopting this approach, but the strictness with which Gebhard has been enforced in the past casts doubts over the ability of Member States to create workable solutions along these lines. It seems clear based on Inspire Art that the approach would call for tailor-made solutions for each specific home state-host state pair, since the necessity of

\footnotetext{
202 See e.g. PL Davies, EP Schuster, and E Van de Walle de Ghelcke, 'The Takeover Directive as a Protectionist Tool?' (2010) ECGI Law Working Paper No. 141/2010, available at http://ssrn.com/paper=1554616.

203 See e.g. Rickford, supra n 6, 1238-1243.

204 See Forum Europaeum Corporate Group Law, 'Corporate Group Law for Europe’ (2000) 1 European Business Organization Law Review 165; on this and other failed harmonisation projects see e.g. Armour and Ringe, supra $\mathrm{n} 15$.

205 Note also that partial harmonisation is unlikely to solve the problem.

206 This is what Armour (supran 1 at 403-404) terms the 'partition theory'.

207 See text to n 166-183.
} 
'intrusive' legislation can only be assessed against the situation created by this particular pairing. In a single market, such tailoring of national legal systems to each of the possible pairings is clearly neither a workable nor a desirable solution to our problem.

It appears to us that the most efficient way to address the problem - at least as far as creditor protection in the vicinity of insolvency is concerned - would be to use a single connecting factor for both company law and insolvency law. ${ }^{208}$ It is clear that this approach would not solve all problems, since, as we have shown above, the interdependencies go beyond company and insolvency law; in fact, it may create new problems, for example by being less responsive to the needs of certain types of creditors who expect the application of the law of the COMI. However, it seems that at this stage of integration of Member States' domestic laws it is virtually unavoidable that some friction remains, at least if one wants to maintain choice of law in this area. ${ }^{209}$ On the other hand, the main source of friction is the lack of alignment between insolvency and company law. The potential negative effects of the single connecting factor approach are likely to be outweighed by the benefits of legal certainty, foreseeability, and the minimisation of regulatory gaps or the accumulation of legal strategies, which entail distortions in the form of over-incentivising or impeding the use of the Treaty's free movement rights. ${ }^{210}$

It is submitted that the case for this approach is particularly strong in light of the different regulatory strategies used by Member States when addressing the vicinity of insolvency problem. The debate about 'abusive transfers of COMI'211 clearly shows that the current COMI approach falls short of offering the kind of protection to creditors it was designed to achieve. Instead, it creates inefficient equilibria, as creditors cannot prevent change of the COMI - since this is a mere factual change they have no control over - and should therefore rationally price their financial exposure to the company assuming that the company will open insolvency proceedings in what is from their perspective the least beneficial

\footnotetext{
208 See Armour, supra n 1, and Ringe (2008), supra n 2, who also suggest 'tying COMI to the place of registered office'.

${ }^{209}$ Note that a single connecting factor solution could in theory also be achieved by requiring companies to keep their headquarters in the country of incorporation. If adopted by all Member States, the effect would resemble a Union-wide application of the real seat theory without, however, constituting a breach of the Establishment chapter; see the Cartesio decision, supra n 22, declaring a Hungarian rule to this effect compatible with the Treaty. This is also the solution adopted for the SE (Art 7 of the SE Statute); see on this WG Ringe, 'The European Company Statute in the Context of Freedom of Establishment' (2007) 7 Journal of Corporate Law Studies 185, questioning the compatibility of this provision with the Treaty. After the Court's holding in Cartesio, however, it seems that such a solution would indeed be compatible with the Treaty, even though it would effectively remove choice of law in this area.

210 See supra A.

211 See Proposal for a Regulation of the European Parliament and of the Council amending Council Regulation (EC) No 1346/2000 on insolvency proceedings, COM(2012) 744 final (12.12.2012), available at <http://ec.europa.eu/justice/civil/files/insolvency-regulation en.pdf $>$; see e.g. Ringe, supra n 2; F Mucciarelli, 'The Hidden Voyage of a Dying Italian Company, from the Mediterranean Sea to Albion' (2012) 9 European Company and Financial Law Review 571; Armour, supra n 1 at 408.
} 
insolvency jurisdiction. This jurisdiction will differ depending on the type of creditor, and thus different creditors may assume different 'least beneficial' insolvency laws, leading on aggregate to the mispricing of corporate debt. Even absent abuse, or prescient regulatory arbitrage, the incompatibilities described here have the potential to cause friction and legal uncertainty for companies with crossborder operations. Subjecting the company to the insolvency law of the incorporation state, on the other hand, would likely increase legal certainty, minimise the friction arising from incoherent and conflicting legal rules, and potentially lead to more efficient pricing of company's debt, as creditors can rely on the application of a known and coherent legal system. ${ }^{212}$ Moreover, a company's changing of the connecting factor for insolvency law would only be possible in 'lockstep' with a change of the applicable company law. Since reincorporation always requires disclosure as well as some sort of regulatory or court intervention, creditor protection mechanisms could easily be attached to this procedure - as they currently are for cross-border mergers. 213

\footnotetext{
212 See Armour, supran 1 at 411.

${ }^{213}$ See Art 4(2) of the Cross-border Merger Directive (Directive 2005/56/EC on cross-border mergers of limited liability companies, OJ L 310/1).
} 